\title{
RENIN AND ANGIOTENSIN
}

\section{A survey of some aspects}

\author{
J. J. Brown, B.Sc,. M.B., B.S., M.R.C.P.
}

A. F. Lever, B.Sc., M.B., B.S., M.R.C.P.
D. L. Davies, M.B., B.S.

J. I. S. Robertson, B.Sc., M.B., B.S., M.R.C.P.

St. Mary's Hospital, London, W.2.

THE APPEARANCE of an article on renin and angiotensin in a symposium devoted to hypertension may suggest that these substances have a function in hypertension which is set apart from their role in normal physiology. Any such impression would be misleading. Renin, angiotensin, aldosterone, sodium balance, and renal function remain closely inter-related irrespective of the height of the arterial pressure. We have, therefore, attempted a wider survey in the hope that this may, in the process, clarify some aspects of hypertension.

This review is unbalanced in at least two respects. Firstly, while the extent of the regions which remain unexplored can only be surmised, it seems likely that a disproportionately detailed knowledge of the adrenocortical relationship of renin and angiotensin has been acquired as compared with their possible intrarenal function. Secondly, we have deliberately considered in most detail those aspects with which we have personal acquaintance. We have, however, attempted to give a guide to the very extensive literature of the subject. Finally, while indulging in several speculations, we have tried to indicate these clearly, since we do not intend them to live longer than the facts permit.

Renin is an enzyme present in kidney extracts (Tigerstedt \& Bergman, 1898; Pickering \& Prinzmetal, 1938; Haas \& Goldblatt, 1963; Kemp \& Rubin, 1962; Peart, Lloyd, Payne, Stone, Thatcher \& Lever, 1965), which acts on a plasma substrate (Braun-Menendez, 1956; Skeggs, Lentz, Hochstrasser \& Kahn, 1963; Lever, Robertson \& Tree, 1964; Cook \& Lee, 1965 ) to form a decapeptide, angiotensin (Peart, 1955, 1956; Elliott \& Peart, 1956; Skeggs, Marsh, Kahn \& Shumway, 1955). The decapeptide is converted to octapeptide angiotensin by a peptidase (or peptidases) present in blood (Skeggs, Marsh, Kahn \& Shumway, 1954; Skeggs, Kahn \& Shumway, 1956).

In the mammalian kidney, renin is closely associated with the vascular pole of the glomerulus (Cook, Gordon \& Peart, 1957; Bing \&
Wiberg, 1958; Cook \& Pickering, 1959; Cook, 1960), although at present it remains undecided whether the macula densa (Bing \& Wiberg, $1958)$ or the granular cells of the afferent arteriole (Hartroft, Sutherland \& Hartroft, 1964) are the major storage site (see reviews by Bing, 1963; Cook, 1963).

Although the presence of renin in blood was long disputed, it is now known that small quantities circulate in peripheral venous and arterial plasma (Lever, Robertson \& Tree, 1963; Lever \& Robertson, 1964; Brown, Davies, Lever, Robertson \& Tree, 1964 k,l).

In blood samples taken simultaneously from a peripheral vein and from a renal vein, renin concentration was systematically higher in renal venous plasma. When peripheral venous renin concentration was normal, the mean ratio of the renal venous to peripheral venous concentration was 1.25 (33 pairs of observations in 17 patients). In conditions in which the peripheral renin level was abnormally high, the difference between the renal venous and peripheral venous plasma concentrations was usually considerably greater (Brown, Davies, Lever \& Robertson unpublished observations).

In similar studies in the dog, a higher renin concentration was usually found in renal venous than in renal arterial plasma (Skinner, Brown, Davies, Lever \& Robertson, unpublished).

Renin-like enzymes have also been demonstrated in renal lymph (Lever \& Peart, 1962) and in urine (Brown, Davies, Lever, Lloyd, Robertson \& Tree, 1964c; 1965b). Renin thus has three possible routes of exit from the kidney, all of which must be taken into account in estimating the rate of renin release.

In mammals, renin-like enzymes have in addition been demonstrated in the uterus and placenta (Stakemann, 1960; Gross, Schaechtelin, Ziegler \& Berger, 1963; Ferris \& Mulrow, 1965), in arterial walls (Dengler, 1956; Gould \& Skeggs, 1963), in salivary glands (Werle, Baumeister \& Schmal, 1962), and in amniotic fluid (Brown, Davies, Doak, Lever, Robertson \& Tree, 1964b). 
Pressor substances resembling mammalian renin have also been extracted from the kidney and from the corpuscle of Stannius of the European eel (Chester Jones, Henderson, Chan, Rankin, Mosley, Brown, Lever, Robertson \& Tree, 1966).

Circulating angiotensin is less easy to detect and its identity therefore less easy to establish than is renin, but its presence has been reported in blood (Kahn, Skeggs, Shumway \& Wisenbaugh, 1952; Langford \& Day, 1961; Scornik \& Paladini, 1961; Morris, Robinson \& Scheele, 1964); plasma (Boucher, Veyrat, de Champlain \& Genest, 1964; Mulrow, 1964), and renal lymph (Lever \& Peart, 1962).

\section{Actions of Renin and Angiotensin}

As far as is known, the various physiological actions of renin are all mediated by angiotensin. Although decapeptide angiotensin has pharmacological effects on certain tissues (see Page \& Bumpus, 1961), the octapeptide form has the more prominent physiological actions. Some of the main effects which have been observed are summarised below, but we must emphasize that many of these are known to be closely interrelated, and are far from independent of one another.

(a) Pressor Action. The systemic pressor effect was first noted by Tigerstedt \& Bergman (1898) and continued to attract most attention (see Pickering \& Prinzmetal, 1938; Goldblatt, 1947, 1964; Pickering, 1955; Haas \& Goldblatt, 1964) until recently. A pressor action has been observed also in the pulmonary circulation (see de Bono, Lee, Mottram, Pickering, Brown, Keen, Peart \& Sanderson, 1963).

(b) Effect on Adrenal Medulla. The release of adrenaline by angiotensin was reported by Braun-Menendez, Fasciolo, Leloir \& Munoz (1940), Braun-Menendez, Fasciolo, Leloir, Munoz \& Taquini (1946), and Kaneto, MoCubbin \& Page (1961), and has recently been further examined (Feldberg \& Lewis, 1964). However, the excretion of vanillylmandelic acid (the chief metabolite of adrenaline and noradrenaline) did not change during pressor infusions of angiotensin in 4 human subjects (Vincent, Kashemsant, Cuddy, Fried, Smulyan \& Eich, 1965).

(c) Neurological Actions. Lewis \& Reit (1965) have demonstrated that angiotensin is able to stimulate autonomic ganglia, whilst Laverty (1963) and Benelli, Della Bella \& Gandini (1964) have suggested that some of the effects of angiotensin may be mediated by the nervous system. (d) Release of Kinins. In the carcinoid syn- 气 drome, facial flushes, probably mediated by a $?$ hormone, may be provoked by the intravenous $\stackrel{\mathbb{Q}}{\varrho}$ injection of small doses of several substances, $c$ including catechol amines and angiotensin (Robertson, Peart \& Andrews, 1962). Reasons have been advanced why the released hormone is probably not serotonin, and since bradykinin had earlier been shown to be released by adrenaline and noradrenaline (Hilton \& Lewis, 1956) it was considered a likely candidate (Robertson o and others, 1962). Subsequently, Oates, Mel- $\overrightarrow{0}$ mon, Sjoerdsma, Gillespie \& Mason (1964) provided direct evidence of kinin release in these circumstances. It is thus possible that angiotensin may release kinins, and the timing of the events in provoked carcinoid flushes suggests that this action is not mediated via catechol amines (Robertson and others, 1962). This aspect has been somewhat neglected, but it could be relevant to the hypotension which $\mathcal{E}$ follows infusions of renin and angiotensin (see Blacket, Depoorter, Pickering, Sellers \& Wilson, 1950; Brown, Chapuis \& Robertson, 1963a; 1964a).

(e) Effect on Adrenal Cortex. The recent rapid advance in knowledge of this aspect of the renin-angiotensin system resulted from the con vergence of several widely separated lines investigation.

Deane \& Masson (1951) found that the administration of renin to rats led to histological changes in the adrenal cortex suggestive of increased activity.

Hartroft \& Hartroft (1953) and Tobian (1960a) showed that sodium deprivation caused histological changes in the juxtaglomerular apparatus which suggested increased secretory function, whilst the converse occurred during sodium loading. These and other observations led Gross $(1958,1960)$ to postulate that renin and angiotensin might serve to control sodium excretion by regulating aldosterone secretion. Subsequently, Genest, Nowaczynski, Koiw, Sandor \& Biron (1960) and Biron, Koiw, Nowaczynski, Brouillet \& Genest (1961) showed that angiotensin caused an increase in aldosterone excretion in man. Laragh, Angers, Kelly \& Lieberman (1960a), Mulrow \& Ganong (1961a), Carpenter, Davis, Ayers \& Casper (1961), Bartter, Casper, Delea \& Slater (1961), and BlairWest, Coghlan, Denton, Goding, Monro, Peterson \& Wintour (1962) later demonstrated an increase in aldosterone secretion rate on adminitration of angiotensin to several species.

Whether or not angiotensin stimulates the secretion of other corticosteroids under normal 
physiological conditions is disputed (see Davis, 1963; Slater, 1963; Slater, Barbour, Henderson, Casper \& Bartter, 1965), although there is little doubt that large (and possibly unphysiological) doses are capable of such effects. In recent studies a rise in the peripheral venous plasma concentration of aldosterone was found within 30 minutes of starting intravenous angiotensin administration to normal humans, and was maintained throughout a 2-hour infusion. By contrast, neither plasma cortisol nor corticosterone increased during these experiments (Fraser, James, Brown, Isaac, Lever \& Robertson, 1965).

(f) Effect on Internal Distribution of Electrolytes. Angiotensin may also have an influence on the distribution of electrolytes within the body, promoting the movement of sodium into, and potassium out of, vascular smooth muscle cells (see Friedman \& Friedman 1964, 1965).

(g) Diuretic and Antidiuretic Effects. Both diuretic and antidiuretic responses to renin and angiotensin have been reported (Pickering \& Prinzmetal, 1940; Hughes-Jones, Pickering, Sanderson, Scarborough \& Vandenbroucke, 1949; Croxatto, Barnafi \& Passi, 1952; Nijensohn, 1957; Peart, 1959; Gross \& Turrian, 1960; Peart \& Brown, 1961; Lauler \& Hickler, 1962; Brown \& Peart, 1962; Brown, 1963; de Bono, Lee, Mottram, Pickering, Brown, Keen, Peart \& Sanderson, 1963; Peters, 1962; Brown, Matthew \& Robertson, 1964m; Gantt \& Carter, 1964; Healy, Barcena, O'Connell \& Schreiner, 1965; Langford \& Pickering, 1965), natriuresis and antinatriuresis generally accompanying corresponding changes in water excretion (see Lever, 1965). The nature of the renal response to infused angiotensin varies with the dose, the duration of administration, the height of the arterial pressure, and some aspects of sodium (or steroid) balance (see Soghikian \& Lameyer, 1963; Laragh, Cannon, Bentzel, Sicinski \& Meltzer, 1963; Gantt \& Carter, 1964). For reasons discussed in these papers it is unlikely that the diuretic or antidiuretic effects are a simple consequence either of angiotensinstimulated increases in aldosterone, or of acute changes in renal artery pressure.

(h) Renin and Angiotensin as Local Hormones. The possibility raised in the previous section-that renin and angiotensin may subserve an intrarenal function-will be considered later.

These and other actions of renin and angiotensin are also discussed in more general reviews by Pickering (1955), Braun-Menendez (1956),
Page \& Bumpus (1961), Haas \& Goldblatt (1963), Peart (1965), and Helmer (1965).

The Estimation of Renin and Angiotensin

The different components of the system have been assessed in such a wide variety of ways that it is necessary to emphasize the points of difference. Methods range from the purely qualitative to those whose quantitative accuracy has been accredited with various degrees of reliability.

(a) Histological. In the first category are inferences based on the histological appearance of the juxtaglomerular complex (see Goormaghtigh, 1945; Itskovitz, Hildreth, Sellers \& Blakemore, 1963; Hess, 1963; Hartroft and others, 1964).

(b) Angiotensin. Angiotensin assays have been made on extracts of whole blood (Kahn, Skeggs, Shumway \& Wisenbaugh, 1952; Langford \& Day, 1961; Boucher, Biron \& Genest, 1961; Scornik \& Paladini, 1961; Morris \& Robinson, 1964), and of plasma (Boucher, Veyrat, de Champlain \& Genest, 1964; Mulrow, 1964). The consistency of recovery through these methods, and characterisation of the extracted material have varied considerably. Each of these methods fails to detect circulating angiotensin in a proportion of normal subjects.

Recently a superfusion assay technique of considerable sensitivity has been developed for use in experimental animals (Regoli \& Vane, 1964).

(c) "Direct" Assay of Renin. Renin may be assayed by means of its pressor effect on intravenous injection into an intact animal (Tigerstedt \& Bergman, 1898; Pickering \& Prinzmetal, 1938; Haas \& Goldblatt, 1964). This is a reliable, but relatively insensitive, method which has been used, for example, in estimating the renin content of kidney extracts (Pickering, Prinzmetal \& Kelsall, 1942; Cook and others, 1957). An interesting variant of this principle is the technique of isovolaemic cross-perfusion developed by Rondell, McVaugh \& Bohr (1958), and later used also by Gross, Regoli \& Schaechtelin (1963). All these "direct" assay methods involve calibration against a standard preparation of renin.

(d) Plasma "Renin-activity". The term "renin-activity" estimation (Helmer. 1964; Boucher, Veyrat, de Champlain \& Genest, 1964) has been applied to a group of techniques which, whilst differing in detail, have several features in common. A sample of plasma (or other biological fluid) is incubated in vitro for a fixed period, usually after angiotensinases have been removed or inactivated. The reaction is 
then stopped, and the angiotensin content is estimated (Helmer, 1962; Helmer \& Judson, 1963; Fasciolo, Romero, de Vito \& Cucchi, 1964; Fitz \& Armstrong, 1964; Boucher and others, 1964; Skinner, MoCubbin and Page, 1964; Kirkendall, Fitz \& Armstrong, 1964; Veyrat, de Champlain, Boucher \& Genest, 1964; Conn, Cohen \& Rovner, 1964a). The fact that a method of this type was one of the first which was sufficiently sensitive to demonstrate consistently renin-like activity in biological fluids (Helmer, 1962) has tended to obscure the quantitative limitations. Firstly, the velocity of angiotensin production depends on both the renin concentration and the substrate concentration; when neither is measured independently, the relative contributions of renin and substrate cannot be determined. Secondly, in none of the papers cited above are details of the recovery of either renin or substrate given, so that the relationship of their in vitro concentrations to those prevailing in vivo is unknown. The possible physiological importance of variation in substrate concentration has been stressed by Helmer (1964), whilst the need for accurate measurement of substrate recovery is emphasized by the results of Maebashi, Yoshinaga, Aida, Okuyama \& Oikawa (1965). These workers found that the substrate concentration of human plasma which had been adjusted to $\mathrm{pH} 5.5$ could vary over a very wide range. Thirdly, the influence in such assay systems of any co-factors or inhibitors present in plasma is not known (see Bumpus, 1965). Fourthly, in these techniques only a single estimation of angiotensin in the incubation mixture is made, and they can not therefore necessarily be regarded as measuring the initial velocity of the reaction. This is a serious theoretical objection to the quantitative accuracy of enzyme systems in general (see Dixon \& Webb, 1958), and has been shown to be relevant in practice to this particular reaction (Lever, Robertson \& Tree, 1964).

Pickens, Bumpus, Lloyd, Smeby \& Page (1965) have recently described a method in which the problem of substrate concentration has been partly met, and in which initial velocity measurement is probably achieved unless renin is present in very high concentration. These authors have preferred to retain the term "renin-activity", however, since they have evidence of co-factors or inhibitors in their incubation system. This usage of the term "reninactivity" thus has different connotations from that of Boucher and others (1964).

(e) Substrate Consumption. A rather different approach was developed by Leloir, Munoz, Braun-Menendez \& Fasciolo (1940) who esti-3 mated renin by measuring the consumption of $\stackrel{\mathbb{Q}}{\complement}$ substrate.

(f) Renin Concentration. The renin assay $\overrightarrow{\overrightarrow{\vec{c}}}$ method we have used, and with which this review is mainly concerned, differs from the techniques described above. Renin is extracted $\bar{\omega}$. from plasma (or other biological material), $\vec{\Phi}$ separated from endogenous substrate and angio- $\Omega$ tensinase, and incubated with a fixed concen- $\omega$ tration of a standard substrate. The initial velo- $\overrightarrow{0}$ city of the reaction is measured by assaying the $-\overrightarrow{-}$ angiotensin content of samples taken at varying $\omega_{\sigma}$ intervals from the incubation mixture. The renin concentration is then determined by reference to $\frac{0}{3}$ a calibration curve prepared with serial dilutions of a standard renin of the appropriate species $\stackrel{N}{*}$ (Lever and others, 1964; Brown, Davies, Lever, $\frac{\vec{c}}{\mathrm{~s}}$ Robertson \& Tree, 1964 k, 1). No activators or $\rightarrow$ inhibitors have been detected in plasma extracts $\mathcal{E}$ in any of the situations discussed below.

The extracted enzyme is identifiable as renin on physico-chemical, enzyme kinetic, and 3 pharmacological grounds; and the incubation $\frac{0}{\circ}$ product as angiotensin physico-chemically and $\stackrel{\odot}{\supset}$ pharmacologically.

The method is sufficiently sensitive to deteets renin in the peripheral venous plasma of norma subjects, and in all cases of pathological dẹ pression of renin concentration encountered so far, short of bilateral nephrectomy. Whilst it gives a measure of the in vivo plasma renin $\stackrel{\circ}{\circ}$ concentration within assessable limits of error, $\stackrel{2}{\rightleftarrows}$ it is no more a measure of the in vivo activity of the rate of angiotensin formation than any of the preceding techniques, since measurable substrate, activators, inhibitors and angiotensinase are eliminated from the system. A similar 3 method has been used by Cook and Lee (1965) for the measurement of renin in kidney extracts. Intrarenal Variations in Renin

Goormaghtigh $(1939,1945)$ observed that juxtaglomerular granulation was more markedo in the superficial than in the deep zones of the rabbit kidney, and proposed that this mighto indicate differing quantities of a pressor $\bar{N}$ hormone in these regions.

Assays on pooled glomeruli taken from differ- $N$ ent parts of the rabbit renal cortex subsequently N suggested that more renin was associated witho the superficial than with the deep glomerulio (Cook and others, 1957; Bing \& Wiberg, 1958; Cook \& Pickering, 1959).

The development of a more sensitive assay method permitted the estimation of extractable renin associated with single glomeruli. This 


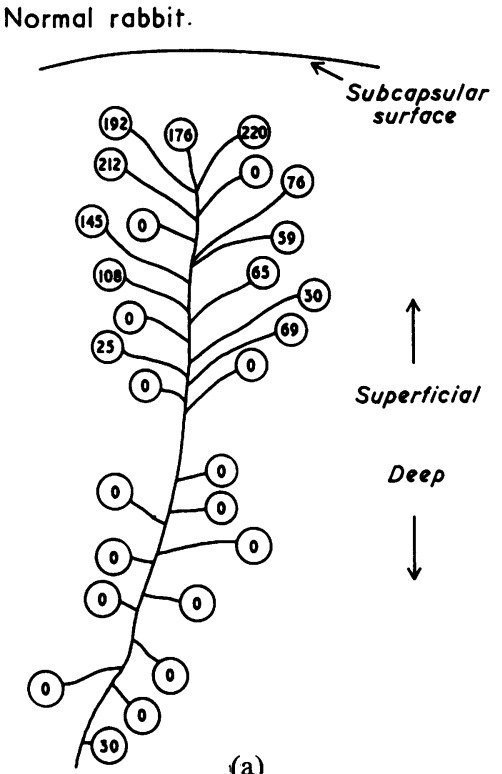

(a)

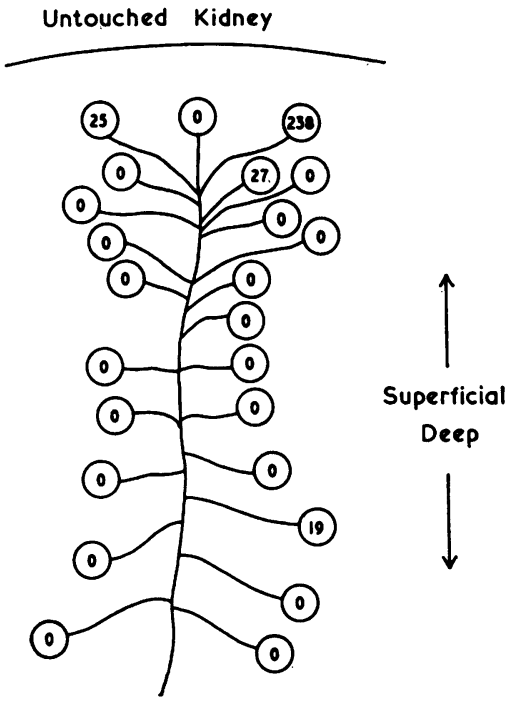

(b)
Fig. 1.-Diagrams of renin quantities associated with single glomeruli along the course of an interlobular artery in the rabbit.

1a. From normal rabbit.

lb. \& lc. From a rabbit with a unilateral renal artery clip. ( $1 \mathrm{~b}$. from untouched kidney; 1c. from clipped kidney).

Renin in units $\times 10,000$. Quantities less than about 0.0017 units are undetectable; these are shown as 0 . (1a. by permission of the Journal of Physiology; lb. and lc. by permission of Clinical Science).

showed that there was a progressive rise in the renin associated with glomeruli along the course of an interlobular artery, renin being usually undetectable in juxtamedullary, and greatest in the most superficial, glomeruli (Fig. 1). This gradation in renin content was paralleled by increasing granularity in the afferent glomerular arteriole, and, rather less closely, by differences in the staining characteristics of the macula densa (Brown, Davies, Lever, Parker \& Robertson, 1963c, d; 1964d; 1965c).

The application of a unilateral renal artery clip was found to lead to an alteration in this distribution, both the extractable renin and the juxtaglomerular granulation increasing in the deep glomeruli distal to the constriction, whilst in the untouched kidney both extractable renin and granulation were low, even in the superficial cortex (Brown and others, 1963c, d; Brown Davies, Lever \& Robertson, 1964j; Parker, 1964; Brown, Davies, Lever, Parker \& Robertson, $1966 \mathrm{~g})$.

These results, which had been anticipated by earlier histological studies, and by renin assays
Clipped Kidney

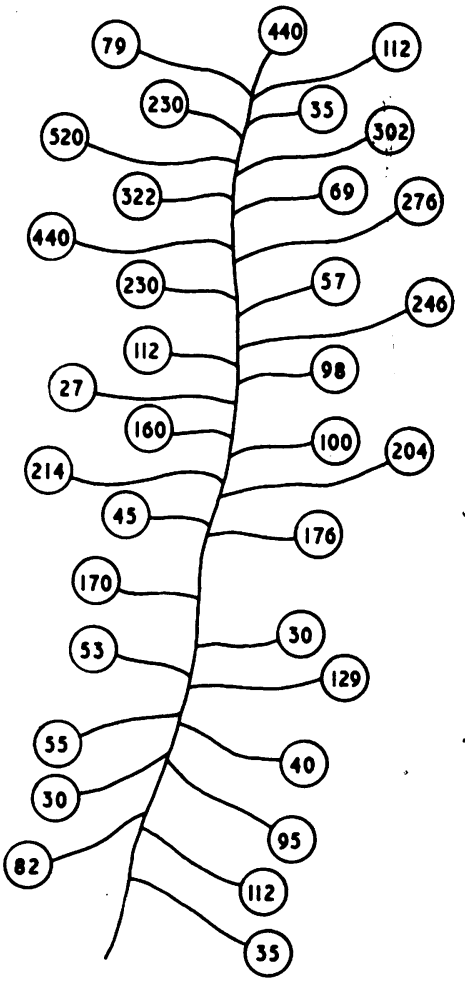

(c)
Superficial Deep

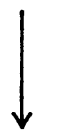


in whole kidney extracts (see Gross, 1960; Tobian, 1960b; Gross, Regoli \& Schaechtelin, 1963) indicate that renin may be influenced by local circulatory modifications, and that its distribution is closely related to the anatomically complex intrarenal circulation (see Trueta, Barclay, Daniel, Franklin \& Prichard, 1947; Moffat \& Fourman, 1963; Fourman \& Moffat, 1964; Lever, 1965; Kriz \& Lever, 1966).

Possible intrarenal functions of renin and angiotensin have been considered by several workers (Goormaghtigh, 1937, 1939; Lever \& Peart, 1962; Schmid, 1962; Bing, 1963; Guyton, 1963; Brown, Davies, Lever, Robertson, 1964; Brown, Davies, Lever, Lloyd, Robertson \& Tree, 1964c; Brown, Matthew \& Robertson. 1964m; Lever, 1965). Roles which have been suggested are that renin is concerned in the regulation of glomerular filtration rate (see Goormaghtigh, 1937, 1939 and 1945; Schmid, 1962; Thurau, 1964); in the control of sodium reabsorption by the renal tubule (Leyssac, 1964; Langford, 1964; Tobian, 1964; Vander \& Miller, 1964); and in changes in the medullary circulation (Lever, 1965).

Whilst the precise nature of any such intrarenal function remains undecided, largely from the absence hitherto of sufficiently sensitive assay techniques, the general concept is one which appears to us extremely attractive. The significance of a local effect is that it might be achieved by alterations in the concentrations of renin and angiotensin which would be insufficient to affect more distant target organs such as the adrenal cortex or medulla. This carries the further implication that the systemic actions of renin and angiotensin may have evolved as secondary (and possibly supplementary) effects.

In this context it is of interest that the adrenal cortex of amphibians such as Necturus (Chase, 1923; Hartman \& Brownell, 1949) is partly embedded within the substance of the kidney close to the glomerulus, a relationship which suggests that a hormone released in the kidney might stimulate the adrenal cortex without entering the general circulation. It is further possible that steroids liberated in this way could also act locally. Bott (1962) has discussed this possibility in relation to the abrupt fall in sodium concentration occurring in the early distal tubule.

\section{Changes in Plasma Renin Concentration in Relation to Sodium Balance and Aldosterone Production}

(a) Physiological Variations. A diurnal cycle of plasma renin concentration occurs in normal subjects, renin values in peripheral venous plasma being slightly higher during the day than in the night (Brown, Davies, Lever \& Robertson, 19661). Small variations also occur in normal women during the menstrual cycle, renin being highest during the luteal phase (Brown, Davies, Lever \& Robertson, 1964h). Plasma concentration of renin is also increased in some, but not all, normal subjects on tilting from the recumbent to the upright posture (Brown, Davies, Lever, MoPherson \& Robertson, 1966f). It is notable that in all of these situations with higher renin some aspect of aldosterone production or plasma aldosterone concentration has been shown to be increased (Muller, Manning \& Riondel, 1958; Nowaczynski, Koiw, Biron, Chretien \& Genest, 1962; Reich, 1962; Wolff \& Torbica, 1963; Bougas, Flood, Little, Tait, Tait \& Underwood, 1964). Plasma renin concentration is increased to a variable extent in normal pregnancy (Brown, Davies, Doak, Lever \& Robertson, 1963b; 1966a). Aldosterone production has also been shown to be high in normal pregnancy, although it is not certain that a strict parallel between renin and aldosterone exists throughout all stages (see Watanabe, Meeker, Gray, Sims \& Solomon, 1963, for references; also Tait, 1964).

(b) Sodium Restriction and Repletion. The relationship between renin and aldosterone is seen most closely in connection with sodium balance in normal subjects, and this provides some of the strongest evidence that the reninangiotensin system includes among its normal functions the regulation of aldosterone production. In man, both aldosterone excretion (Luetscher \& Axelrad, 1954; Luetscher \& Curtis, 1955; Hernando, Crabbe, Ross, Reddy, Renold, Nelson \& Thorn, 1957; Johnson, Lieberman \& Mulrow, 1957; Venning, Dyrenfurth, Giroud \& Beck, 1957; Bartter, Mills, Biglieri \& Delea, 1959) and secretion (Ulick, Laragh \& Lieberman, 1958; Mills, 1962) are inversely related to sodium intake. Sodium restriction leads to a rise in plasma renin concentration, whilst oral sodium loading causes plasma renin to fall (Brown, Davies, Lever \& Robertson, 1963e, 1964g). If a rapid loss of urinary sodium is induced with intravenous frusemide, a concomitant rise in both plasma renin and aldosterone is seen within an hour, whilst neither plasma cortisol nor corticosterone increase (Fraser and others, 1965). Homoeostatic mechanisms limit the extent of sodium loss which can be induced in normal persons by sodium restriction (McCance, 1936), and, prob- 
ably in consequence, the rise in renin which can be induced in this way is not great (Brown and others, 1964g).

(c) Addison's Disease. Sodium homoeostasis is lost in patients with primary adrenocortical insufficiency, in which very high concentrations of plasma renin are found. These return to normal, or near to normal, with steroid replacement therapy (Brown, Davies, Lever \& Robertson, $1963 \mathrm{~g}, 1964 \mathrm{f})$.

In a recent study of a patient with previously untreated Addison's disease (Brown, Fraser, James, Lever, McCusker \& Robertson, 1966c), administration of oral cortisol and 9- $\alpha$-fluorocortisol was accompanied by a rise in plasma sodium, in total exchangeable sodium, and in plasma volume, whilst plasma potassium and renin concentration fell from very high values to normal. External potassium balance and total exchangeable potassium were not, however, greatly altered by treatment.

(d) Sodium-losing Renal Disease. In Addison's disease the renin-angiotensin system may be studied in isolation from the adrenal cortex. Changes in plasma steroids as well as renin may be observed in patients whose ability to retain sodium is impaired because of renal disease. For example, in a patient with bilateral renal calculi and recurrent urinary infections, urinary sodium output was undiminished during three days of sodium restriction. During this time there was a very marked rise in both plasma renin and aldosterone concentration, with a smaller increase in plasma corticosterone during the more severe stages of sodium depletion (Fig. 2). There was no appreciable rise in plasma cortisol in these circumstances, although the response to ACTH was normal (Fraser, James, Brown, Davies, Lever \& Robertson, 1966).

(e) Congestive Cardiac Failure. We have observed two distinct patterns in untreated congestive failure. More commonly, renin concentration has been normal or low, rising with therapeutic diuresis. In other instances, renin has initially been high, and has fallen with treatment. In both treated and untreated cases, there has been a general inverse relationship between plasma sodium and renin concentration (Brown, Davies, Johnston, Lever \& Robertson, 1966e).

Measurement of aldosterone excretion, secretion and metabolic clearance in congestive cardiac failure have given variable results (Deming \& Luetscher, 1950; Muller, Riondel, Manning \& Mach, 1956a; Wolff, Koczorek \& Buchborn, 1957; Ulick and others, 1958; Laragh, 1962b;
Urquhart \& Davis, 1963; Sanders \& Melby, 1964).

Since the metabolic clearance of aldosterone may be impaired in patients with hepatic congestion secondary to cardiac failure (Luetscher, Camargo, Cohn, Dowdy \& Callaghan, 1963; Camargo, Dowdy, Hancock \& Luetscher, 1965; Tait, Bougas, Little, Tait \& Flood, 1965), it is theoretically possible for a high plasma aldosterone concentration to be achieved with a normal or even low aldosterone secretion rate, and hence a low plasma renin concentration. However, in the few cases in which we have studied both, plasma renin and plasma aldosterone have been in close correspondence.

(f) Other Diseases. Other pathological situations in which we have found renin concentration increased are hepatic cirrhosis with ascites (Brown and others, 1963g, 1964f); some, but not all, cases of nephrotic syndrome; and following a large, but not a small, haemorrhage (Brown and others, 1964k; Brown, Davies, Lever, Robertson \& Verniory, 1966m). In more recent studies of experimental haemorrhage in the dog, made in collaboration with Drs. J. R. Vane and R. D. Lowe, concomitant increases in plasma renin concentration and angiotensin generatio were found.

Again, evidence of increased aldosterone production has been observed in all these situations (Farrell, Rosnagle \& Rauschkolb, 1956; Genest 1957; Dyrenfurth, Stacey, Beck \& Venning, 1957; Wolff, Koczorek \& Buchborn, 1958; Muller, 1958; Mulrow \& Ganong, 1961b; Davis, 1962).

Variations in plasma renin concentration in a wide range of circumstances in which arterial pressure is normal (or low) are thus in accord with the concept of the renin-angiotensin system subserving the regulation of aldosterone secretion and sodium balance.

\section{Renin and Angiotensin in Hypertension}

The role of the renin-angiotensin system in hypertension is closely involved with its physiological functions in the regulation of sodium balance and aldosterone secretion.

(i) Relation between Renin and Sodium in Hypertension

Survey of a large series of patients with hypertension revealed an inverse relationship between plasma sodium and renin concentration which extended through the normal range of both, and was independent of aetiology, of the severity of the hvpertension, of complications, and of treatment (Brown, Davies, Lever \& Robertson, 1965g, h; 1966d, k) (Fig. 3). The extremes of this spectrum were represented by 


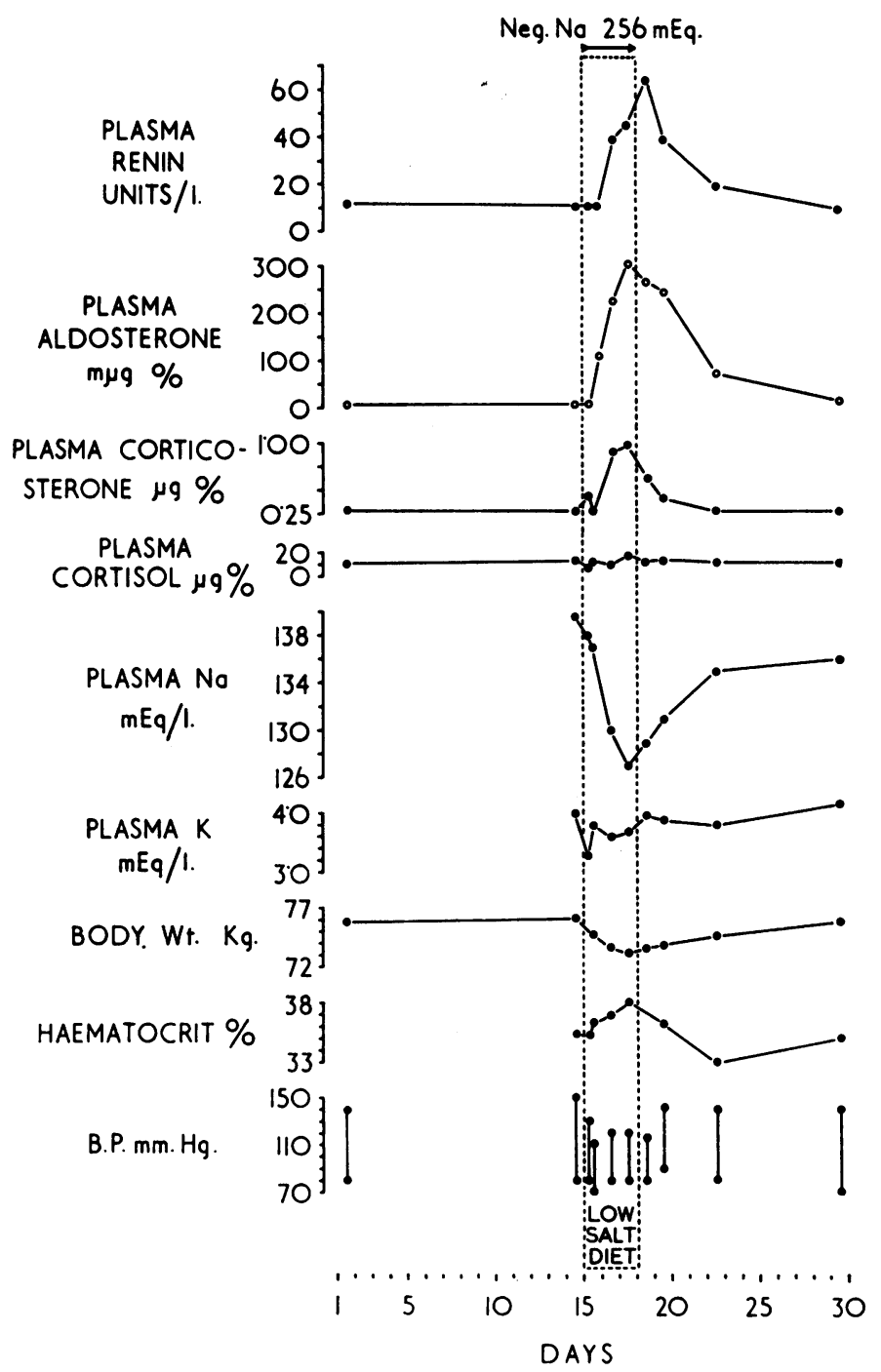

FIG. 2.-Changes in plasma renin and steroids during dietary sodium restriction in a woman with sodium-losing renal disease.

(By permission of Journal of Endocrinology).

two distinct syndromes, both of which were accompanied by increased aldosterone secretion and hypokalaemia.

In one, severe, frequently malignant, hypertension, and usually either renal artery stenosis or some other form of renal disease (see Brown and others, $1965 \mathrm{~g}$ ) were found in association with hyponatraemia and raised plasma renin. The correspondence between the raised plasma renin concentration and aldosterone secretion rate found in a group of patients with this syndrome indicated that the renin-angiotensin sys- tem was probably the drive to aldosterone secre. tion (Brown and others, 1965g; Barraclough, Bacchus, Brown, Davies, Lever \& Robertson, 1965).

The converse situation of elevated plasma sodium concentration with depression of renin was seen in primary hyperaldosteronism (Brown, Davies, Lever \& Robertson, 1963f, 1964f; Brown, Davies, Lever, Peart \& Robertson, 1964e, 1965d)

These two syndromes are contrasted in Fig. 5 . 


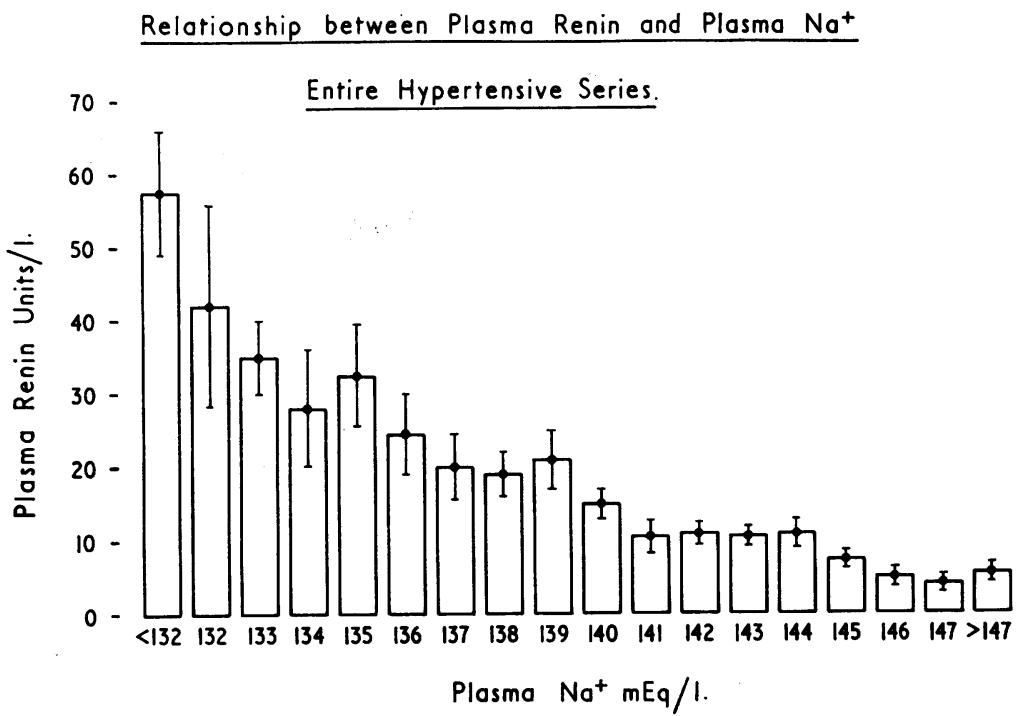

FIG. 3.-Relationship between renin and sodium in hypertensive patients. Mean and S.E.M. shown for renin

(By permission of British Medical Journal).

(ii) Renin in Relation to the Aetiology of the Hypertension

(a) Renal Artery Stenosis. In a group of hypertensive patients with renal artery stenosis (on the combined evidence of arteriographic, pyelographic, and ureteric catheterisation studies), a scatter of renin levels from low normal to a hundred times normal was found. Throughout this wide range renin was closely related inversely to plasma sodium, and directly, although less closely, to the severity of the stenosis. In cases with retinal evidence of the malignant phase plasma renin was invariably high and sodium low; these comprised all the patients with severe stenoses (Brown and others, 165f, g, h) (Fig. 4).

It is noteworthy that roughly 25 per cent of the patients with hypertension and renal artery stenosis had renin values within the normal range (Fig. 4). This observation is in agreement with the finding of normal renin values in a proportion of both rabbits (Lever \& Robertson, 1964) and dogs (Verniory, Enderle, Potvliege, Primo, Gregoire, Vereerstreeten \& Stuckens, 1965; Reinert, Davey, Brown, Davies, Lever \& Robertson, 1966) with experimental renal hypertension, and indicates that plasma renin measurement is a rather less sensitive index of renal artery stenosis than are pyelography, arteriography, and ureteric catheterization studies (see Schlegel, Savlov \& Gabor, 1959;
Brown, Owen, Peart, Robertson \& Sutton, $1960 \% \vec{\circ}$ Stamey, Nudelman, Good, Schwentker \& Hendricks, 1961). This does not, howevet. imply that renin measurement has no prognostic value in relation to renal artery surgery. While the number of cases studied so far is insufficient to provide a definite answer, we have some evidence suggesting that the patients with renal artery stenosis and elevated renin may respond better than those with normal renin to renal artery surgery (Brown and others, 1966k). However, Mulrow (1964) reported successful surgical results in a small number of patients, despite normal preoperative measurements of angiotensin and aldosterone.

(b) Other Renal Lesions. Patients with hypertension due to other forms of renal disease also showed a wide range of plasma renin concentration. Again, this was closely related inversely to plasma sodium, and at the higher levels of plasma renin were encountered cases with the $N$ malignant phase, hypokalaemia, and other features of the hyponatraemic syndrome (Brown and others, 1965h).

(c) "Essential" Hypertension; Coarctation; Phaeochromocytoma. Plasma renin concentration was not abnormal in a small group of cases with hypertension due to phaeochromocy- 7 toma or to coarctation of the aorta. Renin was also in the normal range in a group of patients 
RENAL ARTERY STENOSIS.

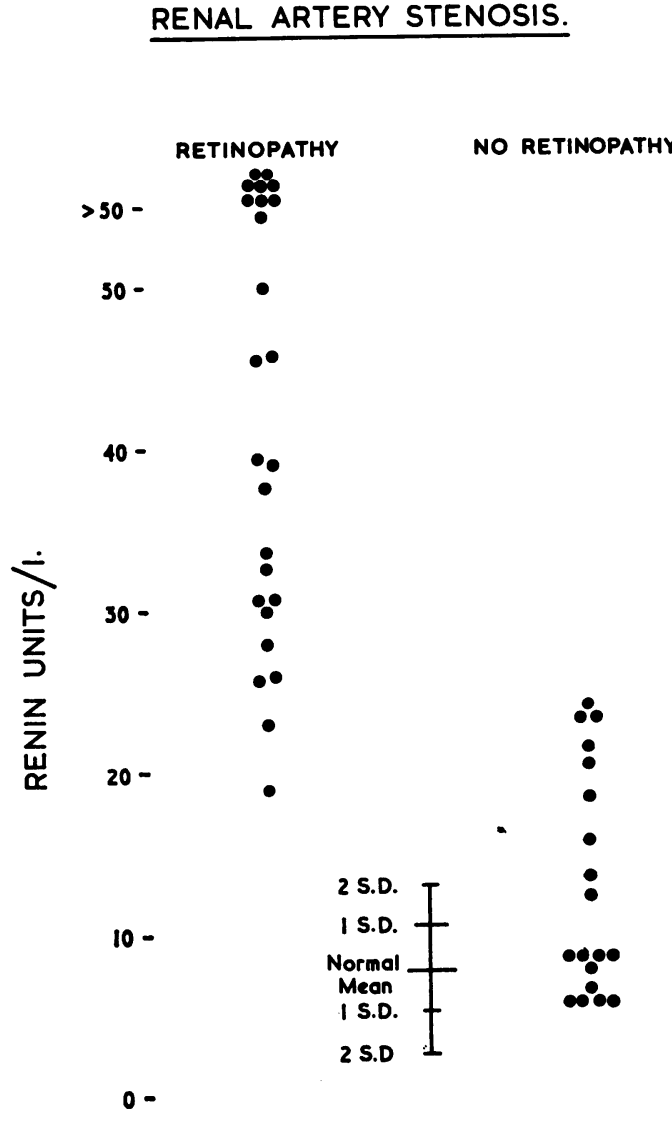

FIG 4.-Renin values in hypertensive patients with renal artery stenosis and retinal haemorrhages and exudates; and in similar cases without retinal lesions.

(By permission of British Medical Journal).

with hypertension of undetermined cause (Brown and others, 1965h).

(d) Hypertension due to Adrenal Cortical Overactivity. The hypernatraemia and low plasma renin concentration in patients with primary hyperaldosteronism have already been mentioned in this review, and have been previously discussed in detail in a series of papers (Brown and others, 1963f, g; 1964e, f; 1965d, g, h; 1966d).

Renin and sodium were normal in three patients with Cushing's syndrome and hypertension, but in a fourth case, where sodium was abnormally high, renin was low (Brown and others, 1965h).

(e) Hypertensive Disease of Pregnancy. As we have noted arove, circulating renin is increased in normal pregnancy (Brown and others, 1963b). In "pre-eclamptic toxaemia" plasma 


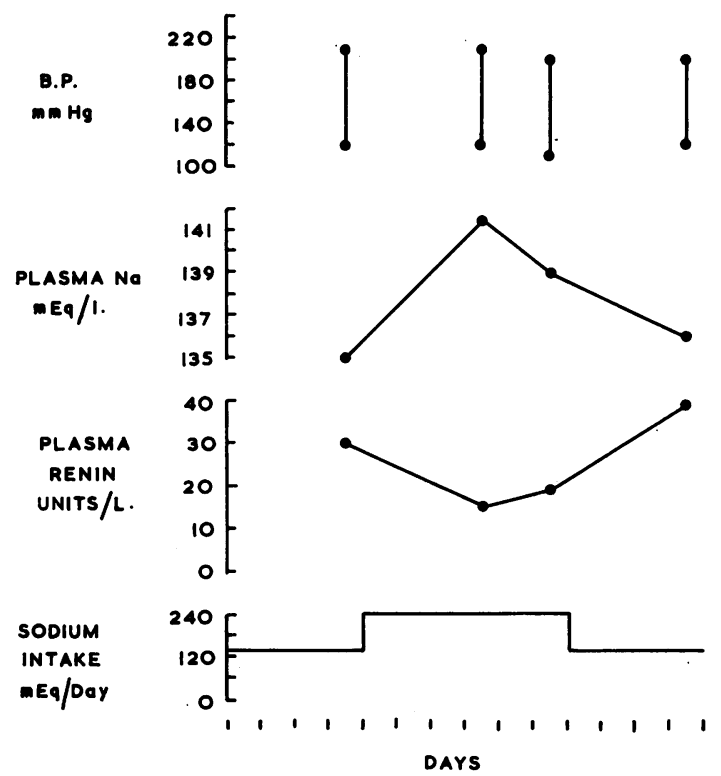

FIG 6.-Effect of oral sodium loading on plasma renin and plasma sodium in a patient with severe hypertension, renal artery stenosis, hypernatraemia and hypokalaemia.

1966d). Our results are thus in accord with the view that the vascular lesions of malignant hypertension are a consequence of increased intra-arterial pressure (Wilson \& Pickering, 1938; Wilson \& Byrom, 1939; Pickering, 1955; Byrom, 1963), and do not support the suggestions made by Laragh, Cannon \& Ames (1963) and Conn, Knopf \& Nesbit (1964b), that the combination of increased circulating angiotensin and aldosterone is required to produce the malignant phase. It is, however, possible that a raised plasma renin, and hence increased angiotensin concentration, might facilitate the occurrence of lesions in the retina more readily than at other sites, possibly because of focal retinal anoxia (Brown and others, 1966d).

(b) Hypertensive Heart Failure: Hypertensive heart failure conformed to the pattern most commonly seen in other forms of congestive failure, in which plasma renin concentration was low initially, rising, sometimes to abnormally high levels, with vigorous diuretic therapy (Brown and others, 1966d).

(c) Chronic Renal Failure: In patients with hypertension and chronic renal failure, a wide range of plasma renin concentration was seen, probably reflecting the instability of sodium balance in these patients. It was notable that high plasma renin values might occur even with grossly impaired excretory function. In two patients, bilateral nephrectomy was followed by a fall in plasma renin concentration to very low levels (Brown and others, 1966d).

(iv) Effect of Treatment of the Hypertension on Plasma Renin Concentration

(a) Hyponatraemic Hypertensive Syndrome: Where this combination of features was associated with renal artery stenosis, surgical correction of the lesion was seen to be followed by elevation of the low plasma sodium and low plasma potassium, and reduction of the increased plasma renin concentration, aldosterone secretion rate, and blood pressure to normal, with resolution of the lesions of the malignant phase $\overrightarrow{\vec{\omega}}$ (Brown and others, 1965f; 1966k; Barraclough ${ }_{\rho}^{\omega}$ and others, 1965; Barraclough, 1966). Similar $\overline{8}$ results were also observed following unilateral 3 . nephrectomy. Furthermore, effective drug treatment may be achieved in these cases, and we have observed a fall in renin and rise in sodium to normal during guanethidine ther- $\vec{v}$ apy before operation in one patient with a renal $\mathrm{\omega}$ artery stenosis. In another patient with uni- 웅 lateral renal artery occlusion, mild hypo- $\rightarrow$ natraemia, and elevated plasma renin concen- 3 tration, oral sodium loading corrected the plasma electrolytes and renin, although arterial $\stackrel{5}{ }$ pressure was unaffected (Fig. 6).

(b) Primary Hyperaldosteronism. Remova of an aldosterone-producing adrenal tumotï may be followed by a fall in plasma aldosterone and plasma sodium, and a rise in plasma renin concentration to normal (Brown and others, 1964e, 1965d). Of much $\frac{}{\circ}$ greater theoretical interest is the observation $\overrightarrow{\vec{P}}$ that spironolactone treatment, while leaving $\frac{\rho}{3}$ aldosterone secretion unaltered, can correct the other abnormalities, including blood pressure and plasma renin concentration (Brown and others, 1963f, g; 1964e, f; 1965d; 1966k).

Spironolactone therapy also has practical application in this condition as an alternative $\stackrel{3}{3}$. which may be preferable to total adrenalectomy $\delta$ (Relman, 1963; Slaton \& Biglieri, 1965) in cases where the adrenal tumour cannot be located at 0 operation (Brown and others, 1963f, g, 1964e, f, 1965d, f, 1966k).

c) Drug Treatment of Hypertension. The use $N$ of thiazides or spironolactones as adjuncts toother forms of hypotensive therapy may lead to $\tilde{D}^{2}$ an elevation of plasma renin, irrespective of $\underset{\omega}{\mathcal{N}}$ aetiology. The inverse relationship between plasma renin and sodium was close in theseo patients, whereas no significant correlation with $\mathbb{D}$ plasma potassium was found (Brown and $\stackrel{?}{?}$ others, 1965g).

Diuretics apart, successful drug treatment of $\frac{\overrightarrow{0}}{\mathrm{O}}$ hypertension tended to restore renin to the 
normal range if it was raised before treatment, and to leave it unchanged if it was initially normal (Brown and others, 1966k).

\section{The Control of Plasma Renin Concentration}

As discussed earlier, renin enters the kidney in renal arterial blood, and leaves in the venous blood, lymph and urine. Setting aside the question of the relative distribution of the enzyme between red cells and plasma, estimation of the net rate at which renin is released into renal venous plasma requires measurement of the renin concentration in both renal arterial and venous plasma, and also of the renal plasma flow. It should, in addition, be emphasized that as "renin activity" determinations (see earlier) do not measure the concentration of renin, such methods cannot validly be used to compute either arteriovenous differences of the enzyme or its rate of secretion.

Moreover, as we have stressed before (Brown and others, 1964k, 1, 1966m), it cannot be inferred that changes in the concentration of renin in peripheral plasma are necessarily the result of changes in the rate at which renin is released. Alterations in the rate of clearance from blood could also be important. At present it is undecided whether changes in plasma renin concentration are achieved by modifications of renin secretion rate, or in its disposal, or by a combination of events. It is, nevertheless, possible to consider some of the influences on plasma renin concentration.

(a) Aldosterone. Studies of several conditions show that plasma renin concentration is not governed directly by either the plasma concentration of aldosterone or by the aldosterone secretion rate. Thus we found the intravenous infusion of aldosterone in two subjects $(1000$ $\mu \mathrm{g}$. in 5 hours) did not lower plasma renin concentration. Similarly, the treatment of primary hyperaldosteronism with a spironolactone leads to elevation of the initially low plasma renin concentration to normal or high normal levels, whilst the raised aldosterone secretion rate can remain unchanged (Brown and others, 1963 f, g, 1964 e, 1965 d). Further, when the normal renal response to aldosterone is impaired because of renal disease, both aldosterone and renin concentrations in plasma may rise together (Fraser and others, 1966; Fig. 2). A concomitant rise in plasma renin and aldosterone has also been observed following the administration of frusemide to normal subjects (Fraser and others, 1965).

(b) Plasma Sodium Concentration. We have already referred to the inverse relationship between plasma renin and sodium concentration found in hypertension (Brown and others, $1965 \mathrm{~g}$ ), cardiac failure (Brown and others, 1966 e), Addison's disease (Brown and others, $1963 \mathrm{~g}, 1964 \mathrm{f}, 1966 \mathrm{c})$, and sodium-losing renal disease (Brown and others, 1965f; Fraser and others, 1966); (Fig. 2). Plasma sodium has been found to be relatively low in several of the other situations in which an increase in renin occurs, such as dietary sodium restriction, cirrhosis with ascites, the luteal phase of the menstrual cycle, and normal pregnancy (see McCance, 1936; Sherlock, 1963; Fawcett and Wynn, 1956; Gray, Munro, Sims, Meeker, Solomon and Watanabe, 1964).

These data suggest that the plasma level of sodium may be one factor controlling the plasma renin concentration; alternatively, renin could be affected by some other aspect of sodium balance of which the plasma sodium concentration is merely an indicator. Plasma sodium, however, cannot be the sole determinant of plasma renin, since renin increased with the sodium diuresis following intravenous frusemide although plasma sodium was not altered detectably (Fraser and others, 1965); and the hyponatraemia of inappropriate oversecretion of ADH is not accompanied by a corresponding rise in plasma renin concentration (Brown, Davies, Lever and Robertson, 1965 e).

(c) Plasma or ECF Volume. The work of Bartter, Liddle, Duncan, Barber and Delea (1956), Bartter and others (1958), and Muller, Riondel and Mach (1956b) suggested that aldosterone secretion might be related to plasma (or extracellular fluid) volume. Whilst a diminution in plasma volume might, similarly, result in an elevation of plasma renin concentration (and vice versa), this again cannot be the sole influence on plasma renin, as changes in plasma volume and renin are not inversely related in normal pregnancy (see Hytten and Paintin, 1963; Low, Johnson and McBride, 1965), or in patients with inappropriate oversecretion of $\mathrm{ADH}$ (Brown and others, 1965 e). Furthermore, spironolactone treatment of a patient with an aldosterone-secreting adrenal adenoma restored abnormally low plasma renin into the normal range, although the volumes of both plasma and extracellular fluid remained well above the predicted normal values (Brown and others, $1965 \mathrm{~d})$.

These observations suggest that plasma volume and plasma sodium concentration (or some other aspects of fluid distribution and of 
sodium balance of which these are indices) may independently affect plasma renin concentration, so that renin is high when both plasma volume and plasma sodium are low (as in sodium depletion), renin is low when both are increased (as in primary hyperaldosteronism), and renin may be normal in the rather less common circumstances when plasma volume and sodium concentration move in opposite directions (as in patients with excess ADH).

(d) Changes in Renal Circulation. Renin may also be influenced by changes in the renal circulation, since there is evidence that the renin concentration of renal lymph (Lever and Peart, 1962), of peripheral arterial plasma (Lever and Robertson, 1964), and of renal venous plasma (Skinner and others, unpublished) may increase following the application of a renal artery constriction. The duration of these effects has not, however, been established.

We have found no evidence to date of any simple relationship between arterial pressure and plasma renin concentration. Thus in experimental haemorrhage, the increase in plasma renin concentration was closely related to the extent of the blood loss (in ml./Kg. body weight), and could not be correlated with changes in mean arterial pressure (Brown and others, $1966 \mathrm{~m}$ ). Further, there was no evidence of depression of renin in patients with hypertension due to adrenal medullary tumours (Brown and others, 1965 h). However, intrarenal circulatory changes may not parallel alterations in systemic blood pressure.

(e) Potassium. Although data have been obtained in both the dog and the sheep indicating that increases in plasma (or serum) potassium may stimulate aldosterone excretion or secretion (see Laragh and Stoerk, 1957; Blair-West and others, 1962; Davis, Urquhart and Higgins, 1963; Wright, $1963 \mathrm{a}, \mathrm{b}$ ), we have not so far observed in man evidence of a direct influence of potassium on plasma renin. Certainly, sodium seems of greater importance in several of the situations studied (Brown and others, 1964 e, f, $1965 \mathrm{~g}, 1966 \mathrm{c}, \mathrm{k}$ ).

Plasma renin concentration thus seems to be sensitive either to a variety of different stimuli, or to an as yet unidentified common stimulus.

(f) Intrarenal Aspects of the Control of Plasma Renin. Despite extensive work, the precise location of renin within the kidney remains uncertain (see Bing, 1963; Cook, 1963; Hartroft and others, 1964; Brown and others, 1965 c). Furthermore, the site at which the hypothetical signals to increased renin con- centration are received remains undecided. Both the macula densa (Goormaghtigh, 1937, 1939; Hess and Gross, 1959; Fisher, 1961; Latta, Maunsbach and Cook, 1962; Guyton, 1963; Brown and others, 1964 g; Thurau, 1964; Vander and Miller, 1964) and the afferent glomerular arterioles (Tobian, 1960 a, b; Skinner, MoCubbin and Page, 1964; Brown and others, $1964 \mathrm{~g}$ ) have been considered, as also have more complex functions of renal distensibility (Ogden, 1944; Swann, Railey and Carmignani, 1959; Lowe, 1964).

It is possible on the present evidence that both the afferent glomerular arterioles and the macula densa may receive supplementary or alternative signals. Lever (1965) has proposed a mechanism based on the relation of the capillary circulation to the renal tubule, by which changes in sodium balance and renal artery pressure might both influence plasma renin via the osmolality of the fluid bathing the macula densa (see also Brown and others, $1964 \mathrm{~g}, 1965 \mathrm{c})$. Several of these points have been discussed in more detail in a previous paper (Brown, Davies, Lever and Robertson, 1966 h).

Other Possible Relationships Between Plasma Sodium and Plasma Renin Concentration

So far, elevation of plasma renin concentration has been discussed mainly as a possible consequence of hyponatraemia. The converse relationship, that elevation of plasma renin (and hence angiotensin) may contribute to a fall in plasma sodium also requires consideration. There are several ways in which this might occur.

Inappropriate Urine Concentration with Water Retention

Lever (1965) has suggested that the effects of renin (and angiotensin) on the composition of the urine may partly be due to actions on the renal medullary blood vessels.

Black (1964a) had earlier proposed that a 옥 decrease in medullary blood flow might lead $D$ to the formation of urine which was overconcentrated in relation to the osmolality of body-fluid, and suggested this as one of the causes of hyponatraemia in cardiac failure. The high plasma renin levels found in $\mathrm{W}$ hyponatraemic heart failure thus naise the possibility of a renin-mediated selective $\theta$ reduction of medullary blood-flow (see Black, $\mathbb{D}$ 1965; Lever, 1965; Brown and others, 1966 e); a similar mechanism might operate in hepatic cirrhosis with ascites (see Brown and others, $1963 \mathrm{~g} ; 1964 \mathrm{f})$. 
Inappropriate urine concentration with retention of water and hyponatraemia also occurs in patients with bronchial carcinoma and excess of a vasopressin-like hormone (Schwartz, Bennett, Curelop and Bartter, 1957). The administration of angiotensin can, like the giving of exogenous $\mathrm{ADH}$, lead to a decrease in volume and an increase in osmolality of the urine of patients with diabetes insipidus (Peart, 1959; Del Greco, 1962; de Bono and others, 1963; Gill, Barbour, Slater and Bartter, 1964). Lever (1965) has cited this as evidence in favour of a similar intrarenal vascular action of angiotensin and ADH.

Possible Effects of Endogenous Renin and Angiotensin in Diabetis Insipidus. These observations encourage speculations on the possible contribution of renin to "thiazide antidiuresis" and related phenomena in patients with diabetes insipidus. Meyer (1905) and Bauer and Aschner (1924) noted that diuretics could reduce the polyuria of diabetes insipidus. Thiazides, theophylline, mersalyl, and spironolactone (Meyer, 1905; Kennedy and Crawford 1959); Havard and Wood, 1960, 1961) have all been observed to produce this effect, which can be partly prevented by salt replacement (Havard and Wood, 1961). The polyuria may also be diminished by dietary sodium restriction (Fitz, 1914; Beaser, 1947).

Since plasma renin concentration increases during sodium deprivation, and following treatment with thiazides or spironolactone (see above), it is possible that these antidiuretic responses in diabetes insipidus may at least in part be the result of an increase in endogenous angiotensin (Brown, Lever and Robertson, 1965 j). When we made this suggestion, we pointed out that the phenomenon has been observed in both vasopressin-sensitive and vasopressin-resistant diabetes insipidus. Very shortly after this, Brodehl and Gellisen (1966) reported a case of vasopressin-resistant diabetes insipidus in which angiotensin infusion reduced polyuria and increased urine osmolality.

\section{Extracellular Sodium Depletion}

A rather different explanation of the hyponatraemia observed in some diseases could be that it represents a loss of sodium from the extracellular compartment.

Infused angiotensin is natriuretic in severe hypertension (Nijensohn, 1957; Peart, 1959; Peart and Brown, 1961; Brown and Peart, 1962; Brown and others, $1964 \mathrm{~m}$ ), in cirrhotic ascites, and in normal subjects deprived of sodium (Laragh, 1962a; Laragh, Cannon, Bentzel,
Sicinski and Meltzer, 1963). The natriuretic effect of angiotensin in hypertensive patients may occur independently of acute increases in systemic arterial pressure (Brown and Peart, 1962); it has also been observed in both kidneys, even in cases with severe unilateral renal artery stenosis (Brown and others, $1964 \mathrm{~m}$ ).

A raised renal artery perfusion pressure per se can also cause natriuresis (see Selkurt, 1961), and might thus contribute to the hyponatraemia of severe hypertension.

Extracellular sodium depletion could, in addition, be enhanced by a movement of sodium into cells under the influence of angiotensin (Friedman, Butt and Friedman, 1957; Friedman and Friedman, 1964).

\section{Observations on the Hyponatraemic \\ Hypertensive Syndrome}

Many of the foregoing observations appear relevant to the hyponatraemic syndrome of severe hypertension which is, as we have mentioned previously, the one form of clinical hypertension in which plasma renin concentration is consistently raised (see Brown and others, $1965 \mathrm{f}, \mathrm{g}$ ).

In several reported cases of the syndrome urinary sodium outpuc has appeared inappropriately high for the depressed plasma sodium concentration (Holten and Petersen, 1956; Laidlaw, Yendt and Gornall, 1960; Laragh, Ulick, Januszewicz, Deming, Kelly and Lieberman, 1960 b), although this may not be invariable (Fitzgerald, Fourman, James and Scarborough, 1957).

Measurements of blood- or plasma-volume have given normal or reduced values, in contrast to the typically increased plasmavolume of primary hyperaldosteronism (Yamauchi, Biglieri and Hopper, 1961; Slaton and Biglieri, 1965). In the cases reported by Fitzgerald and others (1957) and by Goldberg and McCurdy (1963) the hyponatraemia could not be explained on the basis of the external balance of electrolytes or water. Whilst the exchangeable potassium was distinctly low in the patient of Fitzgerald and others (1957), exchangeable sodium was more nearly normal. The sodium content of skeletal muscle was abnormally high in this case, whilst potassium was markedly reduced.

\section{Speculations on the Pathogenesis of the Hyponatraemic Hypertensive Syndrome}

In order to understand the pathogenesis of this syndrome, detailed studies during its development and resolution are required since 
compensatory mechanisms probably obscure the picture in the established condition. However, the hyponatraemia in this syndrome may be explained by one or more of the following mechanisms.

(i) External Loss of Sodium: Although metabolic balance data in these patients are scanty, the urinary excretion of sodium seemed inappropriately high in several reported cases. This observation raises the possibility that the hyponatraemia is related to a negative external sodium balance, and that the raised plasma renin concentration is a secondary event, which in turn leads to an increase in aldosterone secretion, to restriction of further sodium loss and to potassium depletion. In favour of this suggestion is the report that blood and plasma volume are reduced in patients of this type (Slaton and Biglieri, 1965).

An increased excretion of sodium in these patients might be explained by the observation that an experimental increase in mean renal artery pressure leads to an increase in sodium excretion (Selkurt, 1951), and that, in man, sodium excretion and arterial blood pressure are correlated (Green and Ellis, 1954). This mechanism would provide a ready explanation for the additional observation that the plasma concentration of both sodium and renin can be returned to normal when the blood pressure is lowered by surgical treatment (Goldberg and MoCurdy, 1963; Barraclough and others, 1965; Brown and others, $1966 \mathrm{k}$ ), or by hypotensive drugs in patients with severe hypertension due to several causes, including unilateral renal artery stenosis (Gill, George, Solomon and Bartter, 1964; Brown, Davies, Lever and Robertson, 1966 k).

As an alternative explanation, it could be argued that the hyponatraemia follows the rise in plasma renin concentration, since a sodium diuresis occurs during brief angiotensin infusions in patients with severe hypertension (Nijensohn, 1957; Brown and Peart, 1962). It should be noted, however, that in these experiments, the increase in urine volume exceeded that required for solute excretion, so that the hyponatraemia cannot be explained by this mechanism alone. Furthermore, when small amounts of angiotensin were infused into hypertensive patients during periods varying from 1-10 days, the diuretic response was not maintained, and a fall in plasma sodium was not observed (Brown, 1963).

(ii) Internal Movement of Sodium. The demonstration that total exchangeable sodium may remain within the normal range in patients with hypertension and hyponatraemia (Fitzgerald and others, 1957; Brown and colleagues, unpublished observations), suggests that a marked loss of sodium from the body is not the sole factor in the development of this condition. Furthermore, the observation of a marked fall in plasma sodium concentration in severely hypertensive patients, without a corresponding change in external sodium balance (Fitzgerald and others, 1957), implies an internal redistribution of sodium, and/or water. This suggestion is supported by the report that the sodium content of skeletal muscle was abnormally high in a patient with this syndrome (Fitzgerald and others, 1957) and by the observation that the sodium content of arterial or arteriolar walls is increased in both experimental and clinical hypertension (see Tobian, 1960 b). This change might be a consequence of the high plasma renin concentration since, in the rat, infusion of angiotensin leads to an increase in arterial wall sodium (Friedman and Friedman, 1964). The rising blood levels of aldosterone might also contribute to internal movements of sodium and potassium (see Woodbury and Koch, 1957\% Bush, 1962). As far as we are aware, the plasmis concentration of ADH has not been measured iff these patients, but an inorease (see below) could ${ }^{+}$ also contribute to a movement of sodium into cells (Friedman and Friedman, 1964).

(iii) Dilutional Hyponatraemia. It might be argued that water retention due to the action of ADH could contribute to the observed hyponatraemia, since blood volume is reduced in patients of this type (Slaton and Biglieri, 1965), and there is evidence that this change leads to an increase in circulating vasopressin (Weinstein, Bern and Sachs, 1960; Share, 1962). However, measurements of urine and plasma osmolality in these patients (Goldberg and McCurdy, 1963) do not suggest vasopressin activity, although interpretation is difficult since, in general, patients with hypokalaemia are relatively insensitive to vasopressin.

Dilution due to increased fluid intake may also contribute to the fall in plasma sodium since many authors have remarked on the development of excessive thirst in various hyponatraemic syndromes (McCance, 1936; see also Strauss, 1957 and Wolf, 1958), including that associated with severe hypertension (Goldberg and MoCurdy, 1963. Furthermore, many descriptions of clinical potassium depletion mention thirst with the other symptoms (Black, 1964 b). 
Relationship Between Plasma Renin Concentration and the Pressor Sensitivity to Injected Renin and Angiotensin

In recent years studies of the reninangiotensin-aldosterone system have brought into prominence two associations. Plasma renin concentration has been shown to be inversely related to sodium balance (and usually, but not invariably, to plasma sodium concentration); while the state of sodium balance is positively related to the pressor effect of infused (or injected) renin and angiotensin* (see Friedman, Butt and Friedman, 1957; Johnston and Jose, 1963; Brown and others, $1963 \mathrm{f}$, g, 1964 f, 1965 f, Imbs and others, 1966; Friedman and Friedman, 1964; Ostrovsky and Gornall, 1964; Halpern, Meyer, Milliez and Lagrue, 1964; Küchel, Horky, Pazourek and Gregorova, 1964 a; Küchel, Horky, Kapitola and Motlik. 1964 b; Ames, Borkowski, Sicinski and Laragh, 1965). A third relationship therefore implied is that the amount of renin or angiotensin required to produce a given rise in arterial pressure is related positively to the prevailing plasma concentrations of these substances.

This is supported by several observations. It has been suggested, for example, that patients with primary hyperaldosteronism, and normal subjects replete with sodium, are particularly sensitive to the pressor effects of angiotensin (see Biron and others, 1962; Kaplan and Silah, 1964). Plasma renin concentration has been shown to be depressed in both these situations (see Brown and others, 1963 e, f, g, 1964 e, f, g).

Conversely, the pressor effects of angiotensin are apparently reduced in several conditionspregnancy (see Chesley, 1965), cirrhotic ascites (Johnston and Jose, 1963; Laragh and others, 1963; Kaplan and Silah, 1964), sodium deprivation (Ames and others, 1965), Addison's disease (Küchel and others, 1964 a), and the syndromes reported by Bartter, Pronove, Gill, MacCardle and Diller (1962) and Desmit (1964) (see also Bryan, Kliman, Gill and Bartter, 1964; and Fraser and others, 1966)in all of which plasma renin concentration has been shown to be raised.

Where measurements are available therefore, it is seen that the plasma renin concentration and the quantity of exogenous renin (or

\footnotetext{
*While it must be appreciated that changes in plasma renin concentration do not necessarily cause parallel changes in angiotensin, in order to simplify the following discussion it has been assumed that in most of the conditions mentioned renin and angiotensin levels move in the same direction.
}

angiotensin) required to produce an increase in arterial pressure are positively related. This inter-connexion might be anticipated also from the observation (see Gaddum, 1959; Blacket and others, 1950) that the pressor effect of an administered substance varies with the logarithm of the dose*. Thus small absolute increments in plasma renin concentration might affect the blood pressure in conditions in which renin is low (such as primary hyperaldosteronism), whilst a large increase in renin would be needed to produce a pressor effect when the circulating renin was high (as in Addison's disease). Kaplan and Silah (1964) similarly suggested that the sensitivity to infused angiotensin might reflect its plasma concentration. It must, however, be emphasized that an explanation of this kind presupposes that the concentration of renin in plasma is within a range capable of affecting blood pressure.

This important proviso has recently been tested in experiments in which pressor infusions of renin into the rabbit (Imbs, Brown, Davies, Lever and Robertson, 1966) and of angiotensin into man (Mulrow, 1964) were associated with three-fold to four-fold increases in the plasma concentrations of these substances, changes which are not large in relation to the wide range of plasma level found in differente clinical circumstances. These infusions were, of course, acute experiments performed in conditions of normal sodium balance.

\section{Conclusions}

It seems entirely possible on the present evidence that renin and angiotensin may be responsible in several ways (including a direct pressor action) for the maintenance of a normal blood pressure and for the development of renal hypertension, despite the wide range of plasma levels found in various circumstances.

Several lines of research have indicated that sodium is an important factor in the pathogenesis of hypertension, and a number of attempts have been made in recent years to synthesize the

\footnotetext{
*It should be borne in mind that the infusion of a very large dose of renin or angiotensin results in an initial rise in arterial pressure which is, however, not sustained, the pressure rapidly declining to basal levels as the infusion continues (see BraunMenendez, 1956; Taggart and Drury, 1940; Blacket and others, 1950; Langford and Allison, 1961; Brown, 1963; Brown, Chapuis and Robertson, 1964a). This failure of pressor responsiveness, which has been termed "tachyphylaxis" cannot, at least in the rabbit, be due to changes in external sodium balance, since we have observed it after bilateral nephrectomy (Brown, Davies, Doak, Lever and Robertson, unpublished).
} 
available evidence into a uniform concept (see Floyer \& Richardson, 1961; Dahl, 1963; Borst \& Borst-de Geus, 1963; Borst, SmorenbergSchoorl, van Leeuwen \& de Vries, 1963; Wilson, 1963; Langford, 1963; Ledingham, 1964; Ledingham \& Cohen, 1964). The relation of these ideas to the present suggestions will be discussed in more detail elsewhere (Brown, Lever \& Robertson, 1966j), but it is probable that, for reasons already given, one way in which sodium retention may provoke hypertension is by "sensitising" the animal to the pressor effects of angiotensin. The pressor sensitivity thus is probably as important as the absolute level of renin or angiotensin.

This work was supported by grants from the Medical Research Council, the British Heart Foundation, the Wellcome Trust, the Endowment Fund, St. Mary's Hospital, and Pfizer Limited.

We are grateful to Drs. Jill IMcCusker, P. B. Doak, V. Johnston, IM. Davey, H. Reinert, W. Kriz, S. L. Skinner, R. D. Lowe and J. R. Vane for allowing us to refer to collaborative studies not yet published.

\section{REFERENCES}

AMES, R. P., BorkowSKI, A. J., Sicinski, A. M. and LARAGH, J. H. (1965): Prolonged Infusions of Angiotensin II and Norepinephrine and Blood Pressure, Electrolyte Balance, and Aldosterone and Cortisol Secretion in Normal Man and in Cirrhosis with Ascites, J. clin. Invest., 44, 1171.

Barraclough, M. A., Bacchus, B., Brown, J. J., DAVIES, D. L., LEVER, A. F. and ROBERTSON, J. I. S. (1965): Plasma Renin Concentration and Aldosterone Secretion in Patients with Renal or Renal Artery Lesions, Lancet, ii, 1310.

Barraclough, M. A. (1966): Amer. J. Med. (In press).

BartTer, F. C., Biglieri, E. G., Pronove, P. and DeleA, C. S. (1958): Effect of Changes in Intravascular Volume on Aldosterone Secretion in Man. in Aldosterone. Eds. A. F. Muller and C. M. O'Connor. pp. 100-110. London: J. and A. Churchill.

Barter, F. C., Casper, A. G. T., Delea, C. and SLATER, J. D. M. (1961): On the Role of the Kidney in the Control of Adrenal Steroid Production, Metabolism, 10, 1006.

BarTter, F. C., LidDle, G. W., DunCaN, L. E., BARBER, J. K. and Delea, C. (1956): The Regulation of Aldosterone Secretion in Man; the Role of Fluid Volume, J. clin. Invest., 35, 1306.

BartTer, F. C., Mills, I. H., Biglieri, E. G. and DELEA, C. (1959): Studies on the Control and Physiologic Action of Aldosterone, Recent Progr. Hormone Res., 15, 311.

BartTer, F. C., Pronove, P., Gill, J. R., MACCARDLE, R. C. and Diller, E. (1962): Hyperplasia of the Juxtaglomerular Complex with Hyperaldosteronism and Hypokalaemic Alkalosis, Amer. J. Med., 33, 811.

BAEUR, J. and AsCHNER, B. (1924): Die Therapeutische Wirkung des Novasurols bei Diabetes Insipidus, $\mathrm{Zbl}$. inn. Med., 45, 682.

BEASER, S. B. (1947): Renal Excretory Function and Diet in Diabetes Insipidus, Amer. J. med. Sci., 213, 441 .
Benelli, G., Della Bella, D. and Gandini, A. (1964): Angiotensin and Peripheral Sympathetic Nerve Activity, Brit. J. Pharmaeol., 22, 211.

BING, J. and WIBERG, B. (1958): Localisation of Renin in the Kidney, Acta path. microbiol. scand., 44, 138.

BING, J. (1963): Morphological and Histochemical Aspects of the Renin-angiotensin System. Boerhaave Symposium: Hypertension. Edited by J. de Graeff, pp. 3-21. Leyden University.

BIRON, P., KoIW, E.,NowaCZYNSKI, W., Brouillet, J., and GenesT, J. (1961): The Effects of Intravenous Infusions of Valine-5 Angiotensin II and other Pressor Agents on Urinary Electrolytes and Corticosteroids, including Aldosterone, J. clin. Invest., 40, 338.

Biron, P., Chretien, M., Kolw, E., and Genest, J. (1962): Effects of Angiotensin Infusions on Aldosterone and Electrolyte Excretion in Normal Subjects and Patients with Hypertension and Adrenocortical Disorders, Brit. med. J., 1, 1569.

BlACK, D. A. K. (1964a): Cardiac Edema, Amer. Heart J., 68, 435.

BLACK, D. A. K. (1964b): Essentials of Fluid Balance, 3rd Edn. Oxford: Blackwell.

BLACK, D. A. K. (1965): Renal Rete Mirabile, Lancet ii, 1141 .

Blacket, R. B., Depoorter, A., Pickering, G. W., SEllers, A. L. and Wilson, G. M. (1950): Hypertension Produced in the Rabbit by Long Continued Infusions of Renin, Clin. Sci., 6, 295.

Blair-West, J. R., Coghlan, J. P., Denton, D. A., Goding, J. R. Munro, J. A., Peterson, R. E. and Wintour, M. (1962): Humoral Stimulation of Aldosterone Secretion, J. clin. Invest., 41, 1606.

Bonar, J., BROWN, J. J., DAviES, D. L., LANGFord, H. G., LEVER, A. F., and ROBERTSON, J. I. S. (1966): Plasma Renin in American Negro Women with Hypertensive Disease of Pregnancy, J. Obstet. Gynaec. Brit. Cwlth. (In press).

BORST, J. G. G., and BORST-DE GEUS, A. (1963): Hypertension Explained by Starling's Theory of Circulatory Homoeostasis, Lancet i, 677.

BorST, IJ. G. G., SMORENBERG-SCHOORL, M. E. VAN LEEUWEN, A. M. and DE VRIES, L. A. (1963): A Homoeostatic Reaction to Deficient Sodium Excretion. Boerhaave Symposium: Hypertension. Ed. J. de Graeff, pp. 118-135. Leyden University.

BoTr, P. A. (1962): Micropuncture Study of Renal Excretion of Water, $\mathrm{K}, \mathrm{Na}$, and $\mathrm{Cl}$ in Necturus, Amer. J. Physiol., 203, 662 .

BOUCHER, R., BIRON, P. and GENEST, J. (1961): Procedure for Isolation and Determination of Human Blood Angiotensin, Canad. J. Biochem., 39, 581 .

Boucher, R., Veyrat, R. DE Champlain, J. and GENEST, J.' (1964): New Procedures for Measurement of Human Plasma Angiotensin and Renin Activity Levels, Canad. Med. Ass. J., 90, 194.

Bougas, J., Flood, C., Little, B., Tait, J. F., Tait, S. A. S. and UNDERWOOD, R. (1964): Dynamic Aspects of Aldosterone Metabolism. Aldosterone, Edited by E. E. Baulieu and P. Robel, pp. 25-50. Oxford: Blackwell.

Braun-Menendez, E., Fasciolo, J. C., Leloir, L. F. and MunOz, J. M. (1940): Farmacologia de la Hipertensina, Rev. Soc. argent. Biol., 16, 398.

Braun-Menendez, E., Fasciolo, i. C., Leloir, L. F., MUNOZ, J. M., and TAQUINI, A. C. (1946): Renal Hypertension. Translated by L. Dexter. Springfield, Illinois: Charles C. Thomas. 
Braun-Menendez, E. (1956): Pharmacology of Renin and Angiotensin, Pharmacol. Rev., 8, 25.

BrodeHL, J., and Gellissen, K. (1966): Die antidiuretische Wirkung des Angiotensins beim Diabetes insipidus, Klin. Wschr., 44, 101.

Brown, J. J., OWen, K., Peart, W. S., Robertson, J. I. S. and SuTton, D. (1960): The Diagnosis and Treatment of Renal Artery Stenosis, Brit. med. J., ii, 327.

Brown, J. J. and PEART, W. S. (1962): Effect of Angiotensin on Urine Flow and Electrolyte Excretion in Hypentensive Patients, Clin. Sci., 22, 1.

Brown, J. J. (1963): Actions of Angiotensin on the Circulation, Mem. Soc. Endocrin. No. 13 "Hormones and the Kidney". Edited by P. C. Williams, pp. 303-316. London: Academic Press.

Brown, J. J., Chapuis, G. and Robertson, J. I. S. (1963 a): Effect of Long-continued Intravenous Infusions of Angiotensin in the Rabbit, Lancet, 1, 1356.

Brown, J. J., Davies, D. L., DoAK, P. B., Lever, A. F. and Robertson, J. I. S. (1963b): Plasmarenin in Normal Pregnancy, Lancet, ii, 900.

Brown, J. J., Davies, D. L., Lever, A. F., PARKer, R. A. and Robertson, J. I. S. (1963c): Assay of Renin in Single Glomeruli, Lancet, ii, 668.

Brown, J. J., Davies, D. L., Lever. A. F., Parker, R. A. and ROBERTSON, J. I. S. (1963d): Renin Distribution in the Normal Rabbit Kidney. Boerhaave Symposium: Hypertension, Ed. J. de Graeff, pp. 222-226. Leyden University.

Brown, J. J., Davies, D. L., Lever, A. F. and Robertson, J. I. S. (1963e): Influence of Sodium Loading and Sodium Depletion on Plasma-renin in Man, Lancet, ii, 278.

Brown, J. J., DAVIEs, D. L., Lever, A. F. and Robertson, J. I. S. (1963f): Plasma Renin in Hypertension, Boerhaave Symposium: Hypertension. Ed. J. de Graeff, pp. 44-48. Leyden University.

Brown, J. J., Davies, D. L., Lever, A. F. and Robertson,, J. I. S. (1963 g): Plasma Renin in Relation to Alterations in Sodium Metabolism, Boerhaave Symposium: Hypertension, Ed. J. de Graeff, pp. 216-221. Leyden University.

Brown, J. J., ChapuIS, G. and Robertson, J. I. S. (1964 a): The Effect of Prolonged Intravenous Infusion of Angiotensin in the Rabbit, Clin. Sci., 26, 165 .

Brown, J. J., Davies, D. L., DoAK, P. B., Lever, A. F., Robertson, J. I. S. and Tree, M. (1964 b): The Presence of Renin in Human Amniotic Fluid, Lancet, ii, 64.

Brown, J. J., Davies, D. L., Lever, A. F. Lloi D, A. M., Robertson, J. I. S. and Tree, M. (1964 c): A Renin-like Enzyme in Normal Human Urine, Lancet, ii, 709.

Brown, J. J., Davies, D. L., Lever, A. F., Parker, R. A. and RobErTSON, J. I. S. (1964 d): Distribution of the Juxtaglomerular Granulation and the Renin Content by Assay of Single Glomeruli in the Rabbit, Ned. T. Geneesk., 108, 2378.

Brown, J. J., Davies, D. L., Lever, A. F., Peart, W. S. and Robertson, J. I. S. (1964 e): Plasma Renin in a Case of Conn's Syndrome with Fibrinoid Lesions: Use of Spironolactone in Treatment, Brit. med. J., ii, 1636.

Brown, J. J., Davies, D. L., Lever, A. F. and
Robertson, J. I. S. (1964 f): Variations in Plasma Renin Concentration in Several Physiological and Pathological States, Canad. med. Ass. J., 90, 201. ®

Brown, J. J., DAVIES, D. L., LeVER, A. F. and c RobertSON, J. I. S. (1964 g): Influence of Sodium Deprivation and Sodium Loading on the Plasmarenin in Man, J. Physiol. (Lond.), 170, 408.

Brown, J. J., Davies, D. L., Lever, A. F. and Robertson, J. I. S. (1964 h): Variations in Plasma Renin During the Menstrual Cycle, Brit. med. J., ii, 1114 .

Brown, J. J., Davies, D. L., Lever, A. F. and RobertSon, J. I. S. (1964 j): The Assay of Renin in Single Rabbit Glomeruli, J. Physiol. (Lond.), 171, 32P.

Brown, J. J., Davies, D. L., Lever, A. F., Robertson, J. I. S. and Tree, M. (1964 k): The Estimation of Renin in Human Plasma, Biochem. J., 93, 594.

Brown, J. J., Davies, D. L., Lever, A. F., Robertson, J. I. S. and Tree, M. (1964 1): The N Estimation of Plasma Renin Concentration in the Dog, Biochem. J., 93, 3C.

Brown, J. J., MatThew, G. K. and Robertson, J. I. S. $(1964 \mathrm{~m})$ : The Effect of Angiotensin on the Function of the Separate Kidneys in Patients with Unilateral Renal Artery Stenosis, Clin. Sci., 26, 381.

Brown, J. J., Davies, D. L., DOAK, P. B., LeVer, A. F., Robertson, J. I. S. and TruSt, P. (1965 a): Plasma Renin in the Hypertensive Disease of Pregnancy, Lancet, ii, 1219.

Brown, J. J., DAvies, D. L., Lever, A. F., Lloy A. M., RobertSon, J. I. S. and TrEe, M. (1965 b) Renin-like Enzyme in Normal Human Urine, Uraћ Digest, 4, 18.

Brown, J. J., Davies, D. L., Lever, A. F., Parker, R. A. and ROBERTSON, J. I. S. $(1965$ c): The Assay of Renin in Single Glomeruli in the Normal Rabbit and the Appearance of the Juxtaglomerular Apparatus, J. Physiol. (Lond.), 176, 418.

Brown, J. J., Davies, D. L., Lever, A. F., PeArt, W. S. and Robertson, J. I. S. (1965 d): Plasma Concentration of Renin in a Patient with Conn's Syndrome with Fibrinoid Lesions of the Renal Arterioles; the Effect of Treatment with Spironolactone, J. Endocr., 33, 279.

Brown, J. J., DAvies, D. L., Lever, A. F. and Robertson, J. I. S. (1965 e): Plasma Renin in Hypertension and in a Patient with Oversecretion of ADH, J. Endocr., 32, v-vii.

Brown, J. J., DAVIES, D. L., Lever, A. F. and ROBERTSON, J. I. S. (1965 f): Relationship between Sodium Balance, Renin and Aldosterone in Physiological and Pathological Situations in Man. CIHTA Symposium on Hypertension. Ed. P. Tcherdakoff. Paris: Expansion Scientifique.

Brown, J. J., DAVIES, D. L., LeVER, A. F. and Robertson, J. I. S. (1965 g): Plasma Renin Concentration in Human Hypertension. I. Relationship between Renin, Sodium, and Potassium, Brit. med. J., ii, 144.

Brown, J. J., Davies, D. L., Lever, A. F. and Robertson, J. I. S. (1965 h). Plasma Renin Concentration in Human Hypertension. II. Renin in Relation to Aetiology, Brit. med. J., ii, 1215.

Brown, J. J., Lever, A. F. and Robertson, J. I. S. (1965 J): Renin in Diabetes Insipidus, Lancet, ii, 1349. 
Brown, J. J., Davies, D. L., DOAK, P. B., LeVer, A. F. and RobertSON, J. I. S. (1966 a): Changes in Plasma Renin Concentration throughout Normal Pregnancy and Following Parturition, J. Endocr. in Press.

Brown, J. J., Davies, D. L., Doak, P. B., Lever, A. F., Robertson, J. I. S. and Trust, P. (1966 b): Plasma Renin Concentration in the Hypertensive Disease of Pregnancy, J. Obstet. Gynaec. Brit. Cwlth. (in press).

Brown, J. J., Fraser, R., James, V. H. T., LeVer, A. F., MCCuSKer, J. and Robertson, J. I. S. (1966 c): The Effect of Steroid Replacement Therapy on Electrolyte Balance and Plasma Renin in Addison's Disease (in preparation).

Brown, J. J., Davies, D. L., Lever, A. F. and Robertson, J. I. S. (1956d.): Plasma Renin Concentration in Human Hypentension. III. Renin in Relation to Complications of Hypertension, Brit. med. J., i, 505.

Brown, J. J., DAVIES, D. L., Johnston, V., LeVER, A. F. and Robertson, J. I. S. (1966 e): Plasma Renin Concentration in Cardiac Failure. (In preparation).

Brown, J. J., Davies, D. L., Lever, A. F., McPherson, D. and Robertson, J. I. S. (1966 f): Effect of Posture on Plasma Renin Concentration, Clin. Sci., 30, 279.

Brown, J. J., Davies, D. L., Lever, A. F., Parker, R. A. and Robertson, J. I. S. $(1966 \mathrm{~g})$ : The Assay of Renin in Single Glomeruli and the Appearance of the Juxtaglomerular Apparatus in the Rabbit following Renal Artery Constriction, Clin. Sci., 30, 223.

Brown, J. J., Davies, D. L., Lever, A. F. and RobertSON, J. I. S. (1966 h): Factors Controlling the Concentration of Renin in Plasma. Proceedings of the German Speaking Society for Nephrology (in press).

Brown, J. J., Lever, A. F. and Robertson, J. I. S. (1966 j): Renin. London: Edward Arnold. To be published.

Brown, J. J., Davies, D. L., Lever, A. F. and Robertson, J. I. S. $(1966$ k): Plasma Renin Concentration in Human Hypertension. IV. Renin in Relation to Treatment, Brit. med. J. (in press).

Brown, J. J., DAVIES, D. L., Lever, A. F. and RobertSON, J. I. S. (1966 1): Variation of Plasma Renin Concentration during a 24 hour Period, J. Endocr., 34, 129.

Brown, J. J., Davies, D. L., LeVer, A. F. Robertson, J. I. S. and VERnIORY, A. $(1966 \mathrm{~m})$ : Effect of Haemorrhage on Plasma Renin Concentration in Man and the Dog, J. Physiol. (Lond.) 182, 649.

Bryan,, G. T., Kliman, B., Gill, J. R., and Bartter, F. C. (1964): Effect of Human Renin on Aldosterone Secretion Rate in Normal Man and in Patients with the Syndrome of Hyperaldosteronism, Juxtaglomerular Hyperplasia, and Normal Blood Pressure, J. clin. Endocr., 24, 729.

Bumpus, F. M. (1965): Factors Affecting Formation and Destruction of Angiotensin. CIHTA Symposium on Hypertension. Edited by P. Tcherdakoff. Paris: Expansion Scientifique.

BusH, I. E. (1962): Chemical and Biological Factors in the Activity of Adrenocortical Steroids, Pharmacol. Rev., 14, 317.

BYROM, F. B. (1963): Nature of Malignancy in Hypertensive Disease, Lancet, i, 516.

Camargo, C. A., Dowdy, A. J. Hancock, E. W. and
Luetscher, J. A. (1965): Decreased Plasma Clearance and Hepatic Extraction of Aldosterone in Patients with Heart Failure, J. clin. Invest.. 44, 356.

Carpenter, C. C. J., Davis, J. O., Ayers, C. R. and CASPER, A. (1961): Relation of Renin, Angiotensin II and Experimental Renal Hypertension to Aldosterone Secretion, J. clin. Invest., 40, 2026.

Chase, S. W. (1923): The Mesonephros and Urogenital Ducts of Necturus Macalosus, Rajinesque, J. Morph., 37, 457.

Chesley, L. C. (1965): Renal Function in Pregnancy, Bull. N.Y. Acad. Med., 41, 811 .

Chester Jones, I., Henderson, I. W., Chan, D. K. O., Rankin, J. C., Mosley, W., Brown, J. J., LEVER, A. F., Robertson, J. I. S. and TREe, M. (1966): Pressor Activity in Extracts of the Corpuscles of Stannius of the European Eel, $J$. Endocr., 34, (in press).

ConN, J. W., CoHen, E. L. and Rovner, D. $\mathbf{R}$. (1964 a): Suppression of Renin Activity in Primary Aldosteronism, J. Amer. med. Ass., 190, 213.

ConN, J. W., KNopf, R. F. and Nesbit, R. $M$. $(1964$ b): Primary Aldosteronism: Present Evaluation of its Clinical Characteristics and of the Results of Surgery. Aldosterone. Eds. E. E. Baulieu and P. Robel. pp. 327-352. Oxford: Blackwell.

CoOK, W. F., Gordon, D. B. and Peart, W. S. (1957): The Location of Renin in the Rabbit Kidney, J. Physiol. (Lond.), 135, 46P.

Cook, W. F. and Pickering, G. W. (1959): The Location of Renin in the Rabbit Kidney, J. Physiol. (Lond.), 149, 526.

Cook, W. F. (1960): Further Observations on the Location of Renin in the Rabbit Kidney, $J$. Physiol. (Lond.), 152, 27P.

CoOK, W. F. (1963): Renin and the Juxtaglomerular Apparatus, Mem. Soc. Endocrin. No. 13 "Hormones and the Kidney" Edited by $P$. C. Williams. pp. 247-254. London: Academic Press.

COOK, W. F. and LeE, M. R. (1965): The Preparation of Rabbit Renin Substrate for the Assay of Minute Amounts of Renin, Biochem. J., 96, 413.

Croxatto, H., Barnafi, L. and Passi, J. (1952): Effect of Renin on Diuresis in Rats, Science, 116, 507.

DAHL, L. K. (1963): Metabolic Aspects of Hypertension, Ann. Rev. Med., 14, 69.

Davis, J. O. (1962): The Control of Aldosterone Secretion, Physiologist, 5, 65.

Davis, J. O. (1963): The Importance of the Reninangiotensin System in the Control of Aldosterone Secretion. Mem. Soc. Endocrin. No. 13 "Hormones and the Kidney". Ed. P. C. Williams. pp. 325-339. London: Academic Press.

Davis, J. O., URQuhart, J. and Higgins, J. T. (1963): The Effects of Alterations of Plasma Sodium and Potassium Concentration on Aldosterone Secretion, J. clin. Invest., 42, 597.

Deane, H. W., and Masson, G. M. C. (1951): Adrenal Cortical Changes in Rats with Various Types of Experimental Hypertension, J. clin. Endocr., 11, 193.

De Bono, E., Lee, G., Mottram, F. R. Pickering, G. W., Brown, J. J., KeEN, H., Peart, W. S. and Sanderson, P. H. (1963): The Action of Angiotensin in Man, Clin. Sci., 25, 123.

DEL Greco, F. (1962): Comparative Effects of Valine-5 Angiotensin II Amide and Pitressin on 
Renal Excretory Function in Diabetes Insipidus, Proc. Soc. exp. Biol. (N.Y.), 109, 105.

DEMING, Q. B. and LUETSCHER, J. A. (1950): Bioassay of Desoxycorticosterone-like Material in Unine, Proc. Soc. exp. Biol. (N.Y.), 73, 171.

DENGLER, H. (1956): Uber einen Reninartigen Wirkstoff in Arterienextrakten, Arch. exp. path. pharm., 227, 481.

DESMIT, E. M. (1964): Hypokalaemic Alkalosis. Water and Electrolyte Metabolism-II. Eds. J. de Graeff and B. Leisjne. pp. 125-133 Amsterdam: Elsevier.

DIXON, M. and WeBB, E. C. (1958): Enzymes. 1st Edn. London: Longmans.

DYRENFURTH, I., STACEY, C. H., BECK, J. C. and VenNing, E. M. (1957): Aldosterone Excretion in Patients with Cirrhosis of the Liver, Metabolism, 6,544 .

Elliott, D. F. and Peart, W. S. (1956): Amino-acid Sequence in a Hypertensin, Nature (Lond.), 177, 527.

FARRell, G. L., Rosnagle, R. S. and RAuschiolb, E. W. (1956): Increased Aldosterone Secretion in Response to Blood Loss, Circulat. Res., 4, 606.

FASCIOLO, J. C., ROMERn, J. C., DE VITO, E. and CuCCHI, J. N. (1964): The Renin Content of the Blood of Humans and Dogs under General Conditions, Canad. med. Ass. J., 90, 206.

FAWCETT, J. K. and WYNN, V. (1956): Variation of Plasma Electrolyte and Total Protein Levels in the Individual, Brit. med. J., ii, 582.

FELDBerG, W. and LeWIS, G. P. (1964): Action of Peptides on the Adrenal Medulla. Release of Adrenaline by Bradykinin and Angiotensin, $J$. Physiol. (Lond.), 171, 98.

FERRIS, T. F. and MULROW, P. J. (1965): The Uterus as a Source of Renin, Clin. Res., 13, 206.

FISHER, E. R. (1961): Correlation of Juxtaglomerular Granulation, Pressor Activity, and Enzymes of Macula Densa in Experimental Hypertension, Lab. Invest., 10, 707.

FITZ, R.'(1914): A Case of Diabetes Insipidus, Arch. intern. med., 14, 706.

FitZ, A. E. and ÁRMSTrong, M. L. (1964): Plasma Vasoconstrictor Activity in Patients with Renal, Malignant and Primary Hypertension, Circulation, 29. 409.

FitzGerald, M. G., Fourman, P., James, A. H. and SCARBOROUGH, H. (1957): Malignant Hypertension, Adrenal Hyperplasia and Depletion of Potassium, Scot. med. J., $2,473$.

FLOYER, M. A. and RICHARDSON, P. C. (1961): Mechanism of Arterial Hypertension: Role of Capacity and Resistance Vessels, Lancet, i, 253.

FOURMAN, J. and MOFFAT, D. B. (1964): Observations on the Fine Blood Vessels of the Kidney, Symp. zool. soc. Lond., 11, 57.

FRASER, R., JAMES, V. H. T., BROWN, J. J., ISAAC, P., LeVer, A. F. and RoberTSON, J. I. S. (1965): Effect of Angiotensin and of Frusemide on Plasma Aldosterone, Corticosterone, Cortisol, and Renin in Man, Lancet, ii, 989.

Fraser, R., JAMES, V. H. T., Brown, J. J., DAvies, D. L., LEVER, A. F. and ROBERTSON, J. I. S. (1966): The Effect of Sodium Restriction on Plasma Aldosterone, Cortisol, Cortic sterone, and Renin Concentration in a Patient with Sodiumlosing Renal Disease, J. Endocr. (In Press.)

FrIEDMAN, S. M., BUT, R. M. and FrIeDMAN, C. L. (1957): Cation Shifts and Blood Pressure Regulation in the Dog, Amer. J. Physiol., 190, 507.
Friedman, S. M. and Friedman, C. L. (1964): Ionic ڤ Basis of Vascular Response to Vasoactive Sub- 3 stances, Canad. med. Ass. J., 90, 167.

Friedman, S. M. and Friedman, C. L. (1965): $\stackrel{\varrho}{c}$

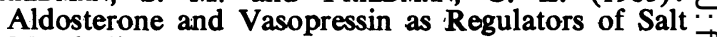
Metabolism and Blood Pressure. CIHTA Symposium on Hypertension. Edited by P. Tcherkadoff. Paris: Expansion Scientifique.

GadDUM, J. H. (1959): Pharmacology; Fifth edition. London: Oxford University Press.

GANTT, C. L. and CARTER, W. J. (1964): Acute $\frac{\widehat{\Phi}}{\mathrm{D}}$ Effects of Angiotensin on Calcium, Phosphorus, $\triangle$ Magnesium and Potassium Excretion, Canad. med. Ass. J., 90, 287.

GENEST, J. (1957): Clinical States Associated with $\vec{\circ}$ Abnormal Aldosterone Excretion, Canad. med. Ass. J., 77, 780.

Genest, J., NOWACZYNSKI, W., KoIW, E., SANDOR, P. and BIRON, P. (1960): Adrenocortical Function 6 in Essential Hypertension. In Essential Hypertension. pp. 126-146. Ed. K. D. Bock and P. T. A Cottier. Berlin: Springer-Verlag.

Genest, J., Boucher, R., DE Champlain, J., Veyrat, $\vec{p}$ R., Chretien, M., Biron, P., Tremblay, G., Roy, of P. and Cartier, P. (1964): Studies on the Renin- $\vec{G}$ angiotensin System in Hypertensive Patients, $\mathcal{W}$ Canad. med. Ass. J., 90, 263.

GiLl, J. R., BARBOUR, B. H., Slater, J. D. H., BARTTER, F. C. (1964): Effect of Angiotensin if $\vec{z}$ on Urinary Dilution in Normal Man, Amer. J. Physiol., 206, 750.

GILl, J. 'R., GeORGE, J. M., SOLOMON, A., and $\stackrel{\Im}{丂}$ BARTTER, F. C. (1964): Hyperaldosteronism and $\vec{\varphi}$ Renal Sodium Loss Reversed by Drug Treatme 8 for Malignant Hypertension. New Engl. J. Mes 270, 1088 .

GoldBerG, M. and MCCURDY, D. K. (1963) Hyperaldosteronism and Hypergranularity of the Juxtaglomerular Cells in Renal Hypertension, Ann. intern.. Med. 59, 24.

GoldBLATT, H. (1947): The Renal Origin of Hypertension, Physiol. Rev., 27, 120.

GolDBLATT, H. (1964): "Hypertension due to Renal Ischemia, Bull. N.Y. Acad. Med., 40, 745.

GoormaGHTIGH, N. (1937): L'appareil Neuro-myoarterial Juxtaglomerulaire du Rein: Ses Reactions en Pathologie et ses Rapports avec le Tube Urinifère, C. R. Soc. Biol. (Paris) 124, 293.

GoORMAGHTIGH, N. (1939): Une Glande Endocrine dans ia Paroi des Artérioles Rénales. Brux-méd., 19, 1541 .

Goormaghtigh, N. (1945): Facts in Favour of an $\delta$ Endocrine Function of the Renal Arterioles, $J$. Path. Bact., 57, 392.

Gould, A. B. and SkegGS, L. T. (1963): The 은 Presence of Renin in Arteries, Fed. Proc., 22, 421. D Gray, M. J., MunRo, A. B., Sims, E. A. H., MEeKER, o C. I., SOLOMON, S. and WATANABE, M. (1964): Regulation of Sodium and Total Body Water $N$ Metabolism in Pregnancy, Amer. J. Obstet. Gynec., 89, 760 .

GREEN,, D. M. and Ellis, E. J. (1954): Sodium స్ Output-blood pressure Relationships and their $\sigma$ Modification by Treatment, Circulation, 10, 536.

GROSS, F. (1958): Renin und Hypertensin, Physiologische oder Pathologische Wirkstoffe, Klin. Wschr., $36 ; 693$.

Gross, F. (1960): Adrenocortical Function and 0 Renal Pressor Mechanisms in Experimental Hypertension. Essential Hypertension. pp. 92-111. Eds. K. D. Bock and P. T. Cottier. Berlin: Springer. 
Gross, F. and Turrian, H. (1960): Polypeptides with Affect Smooth Muscles and Blood Vessels. pp. 137-151. Ed. M. Schachter. Oxford, London, etc.: Pergamon Press.

Gross, F., Regoli, D. and Schaechtelin, G. (1963): Renal Content and Blood Concentration of Renin. Mem. Soc. Endocrin. No. 13 "Hormones and the Kidney". Ed. P. C. Williams. pp. 293-300. London : Academic Press.

Gross, F., Schaechtelin, G., Ziegler, $M$. and Berger, M. (1964): A Renin-like Substance in the Placenta and Uterus of the Rabbit, Lancet, i, 914.

GuYTON, A. C. (1963): Theory for Autoregulation of Glomerular Filtration Rate and Blood Flow in each Nephron by the Juxtaglomerular Apparatus, Physiologist, 6, 194.

HaAs, E. and GoldblatT, H. (1963): Studies on Renin, Biochem. Z., 338, 164.

HaAs, E. and Goldblat, H. (1964): Pressor Effect of Renin, Amer. J. Physiol., 207, 1077.

Halpern, B., Meyer, P., Milliez, P. and Lagrue, G. (1964): Increase in the Sodium Content of Arterial Walls during Experimental Hypertension, Nature. (Lond.), 201, 505.

Hartman, F. A. and Brownell, K. A. (1949): The Adrenal Gland. London: Henry Kimpton.

Hartroft, P. M. and HaRTROFT, W. S. (1953): Studies on Renal Juxtaglomerular Cells I. Variations Produced by Sodium Chloride, and Desoxycorticosterone Acetate, J. exp. Med., 97, 415.

HARTROFT, P. M., Sutherland, L. E. and Hartroft, W. S. (1964): Juxtaglomerular Cells as the Source of Renin: Further Studies with the Fluorescent Antibody Technique and the Effect of Passive Transfer of Antirenin, Canad. med. Ass. J., 90, 163.

Havard, C. W. H. and Wood, P. H. N. (1960): Antidiuretic Properties of Hydrochlorothiazide in Diabetes Insipidus, Brit. med. J., i, 1306.

HavarD, C. W. H. and WoOD, P. H. N. (1961): The Effect of Diuretics on Renal Water Excretion in Diabetes Insipidus, Clin. Sci., 21, 321.

Healy, J. K., Barcena, C., O'ConNell, J. M. B. and SCHREINER, G. E. (1965): Renal and Pressor Action of Angiotensin in the Normal Dog, Amer. J. Physiol., 208, 1093.

Helmer, O. M. (1962): Presence of Renin in Plasma of Patients with Arterial Hypertension, Circulation, 25, 169 .

Helmer, O. M. and Judson, W. E. (1963): The Quantitative Determination of Renin in the Plasma of Patients with Arterial Hypertension, Circulation, 27, 1050

Helmer,, O. M. (1964): Renin Activity in Blood from Patients with Hypertension, Canad. med. Ass. J., 90, 221.

Helmer, O. M. (1965): The Renin-angiotensin System and its Relation to Hypertension, Progr. cardiovasc. Dis., 8, 117.

Hernando, L., Ćrabbe, J., Ross, E. J., ReDdy, W. J., RenOld, A. E., Nelson, D. H. and THORN, G. W. (1957): Clinical Experience with a Physicochemical Method for Estimation of Aldosterone in Urine, Metabolism, 6, 518.

HeSs, R. and Gross, F. (1959): Glucose-6-dehyrdogenase and Renin in Kidneys of Hypertensive or Adrenalectomised Rats, Amer. J. Physiol., 197, 869.

Hess, R. (1963): Considerations on the Histochemistry of Renal and Extrarenal Enzyme Systems wtih Reference to Renin and Angiotensinase. Boerhaave Symposium: Hypertension. Ed. J. de Graeff. pp. 22-37. Leyden University.
Hilton, S. M. and Lewis, G. P. (1956): Relationship between Glandular Activity, Bradykinin Formation and Functional Vasodilatation in the Submandibular Salivary Gland, J. Physiol. (Lond.) 134, 471.

Holten, C. and Petersen, V. P. (1956): Malignant Hypertension with Increased Secretion of Aldosterone and Depletion of Potassium, Lancet ii, 918.

Hughes-Jones, N. C., Pickering, G. W., Sanderson, P. H., SCARBorough, $H$. and VANDENBROUCKe, J. (1949): The Nature of the Action of Renin and Hypertensin on Renal Function in the Rabbit, $J$. Physiol. (Lond.), 109, 288.

HytTen, F. E. and PAINTIN, D. B. (1963): Increase in Plasma Volume during Normal Pregnancy, $J$. Obstet. Gynec. Brit. Cwlth., 70, 402.

ImBS, J. L., BRown, J. J., DAVIES, D. L., LeVER, A. F., and Robertson, J. I. S. (1966): Plasma Renin Concentration in the Rabbit during Pressor Infusions of Renin. (To be published.)

Itskovitz, H. D., Hildreth, E. A., Sellers, A. M., and Blakemore, W. S. (1963): The Granularity of the Juxtaglomerular Cells in Human Hypertension, Ann. intern. Med., 59, 8.

Johnson, B. B., Lieberman, A. H. and Mulrow, P. J. (1957): Aldosterone Excretion in Normal Subjects Depleted of Sodium and Potassium, $J$. clin. Invest., 36, 757.

Johnston, C. I. and Jose, A. D. (1963): Reduced Vascular Response to Angiotensin II in Secondary Aldosteronism, J. clin. Invest., 42, 1411

KahN, J. R., Skeggs, L. T., Shumway, N. P., and Wisenbaugh, P. E. (1952): The Assay of Hypertensin from the Arterial Blood of Normotensive and Hypertensive Human Beings, J. exp. Med., 95, 523 .

Kaneko, Y., McCubbin, J. W. and Page, I. $M$. (1961): Ability of Vasoconstrictor Drugs to Cause Adreno-medullary Discharge after "Sensitisation" by Ganglion-stimulating Agents, Circ. Res., 9, 1247.

Kaplan, N. M. and Silah, J. G. (1964): The Effect of Angiotensin II on the Blood Pressure in Humans with Hypertensive Disease, J. clin. Invest., 43, 659.

KeMP, E. and RubiN, I. (1962): Renin Purification by DEAE Cellulose Chromatography, Scand. J. clin. Lab. Invest., 14, 207.

KENNEDY, G. C. and CRAWFORD, J. D. (1959): Treatment of Diabetes Insipidus with Hydrochlorothiazide, Lancet, i, 866.

Kirkendall, W. M., Fitz, A. E. and Armstrong, M. L. (1964): Hypokalaemia and the Diagnosis of Hypertension, Dis. Chest., 45, 337.

KRIZ, W. and LEVER, A. F. (1966): Countercurrent Exchange of Urea in the Renal Medulla. (To be published).

KuChel, O., Horky, K., Pazourek, and Gregorova, I. (1964a): Pressor Hyporeactivity in Addison's Disease, Lancet, ii, 1316.

KuCHel, O., HoRky, K., Kapitola, J. and Motlik, K. (1964b): Blood-pressure Hyper-reactivity to Angiotensin in Man, Lancet, ii, 1341.

Laidlaw, J. C., YendT, E. R. and Gornall, A. G. (1960): Hypertension caused by Renal Artery Occlusion Simulating Primary Aldosteronism, Metabolism, 9, 612 .

LANGFORD, H. G. and DAY, L. H. (1961): Angiotensin and Renal Hypertension, Clin. Res., 9, 203.

LANGFORD, H. G. and Allison, F. (1961): Arteriolar Changes in Renin Tachyphylaxis, Amer. J. Physiol., 200. 130 . 
LANGFORD, H. G. (1963): An Explanation of Hypertension Produced by Narrowing the Renal Artery, Perspect. Biol. Med., 6, 372.

LANGFORD, H. G. (1964): Tubular Action of Angiotensin, Canad. med. Ass. J., 90, 332.

Langford, H. G. and Pickering, G. W. (1965): The Action of Synthetic Angiotensin on Renal Function in the Unanaesthetised Rabbit, J. Physiol. (Lond.), 177, 161.

LARAGH, J. H., and STOERK, H. C. (1957): A Study of the Mechanism of Secretion of the Sodium-retaining Hormone (Aldosterone), J. clin. Invest., 36, 383.

LARAGH, J. H., ANGers, M., Kelly, W. G. and LIEBERMAN, S. (1960a): Hypotensive Agents and Pressor Substances, J. Amer. med. Ass., 174, 234.

LARAGH, J. H., Ulick, S., Januszewicz, V., Deming, Q. B., Kelly, W. G., and LiebermaN, S. (1950b): Aldosterone Secretion and Primary Malignant Hypertension, J. clin. Invest., 39, 1091.

LARAGH, J. H. (1962a): Interrelationships between Angiotensin, Norepinephrine, Epinephrine, Aldosterone Secretion and Electrolyte Metabolism in Man, Circulation, 25, 203.

LARAGH, J. H. (1962b): Hormones and the Pathogenesis of Congestive Heart Failure, Circulation, 25, 1015.

LARAGH, J. H., CanNoN, P. J., Bentzel, C. J., SiCINSKY, A. M. and MelTZER, J. I. (1963): Angiotensin H, Norepinephrine and Renal Transport of Electrolytes and Water in Normal Man in Cirrhosis with Ascites, J. clin. Invest., 42, 1179.

Laragh, J. H., Cannon, P. J. and Ames, R. P. (1963): Aldosterone Secretion and Various Forms of Hypertensive Disease, Ann. intern. Med., 59, 117.

LatTa, H., Maunsbach, A. B. and COOK, M. L. (1962): The Juxtaglomerular Apparatus as Studied Electron Microscopically J. Ultrastruct. Res., 6, 547.

LAUleR, D. P. and HiCKLER, R. B. (1962): Effect of Angiotensin II on Canine Renal Haemodynamics and Electrolyte Excretion, Fed. Proc., 21, 432.

LAVERTY, R. (1963): A Nervously Mediated Action of Angiotensin in Anaesthetised Rats, J. Pharm. Pharmacol., 15, 63.

LedinghaM, J. M. (1964): The Pathogenesis of Renal Hypertension. Symposium on Advanced Medicine. Editor N. Compston. pp. 3-17. London: Pitman Medical.

LedinghaM, J. M. and COHEN, R. D. (1964): Hypertension Explained by Starling's Theory of Circulatory Homoeostasis, Lancet, i, 501.

Leloir, L. F., Munoz, J. M., Braun-Menendez, E. and Fasciolo, J. C. (1940): Dosaje de la Renina, Rev. Soc. argent. Biol., 16, 635.

Lever, A. F. and Peart, W. S. (1962): Renin and Angiotensin-like Activity in Renal Lymph, $J$. Physiol. (Lond.), 160, 548.

LEVER, A. F. and Robertson, J. I. S. (1964): Renin in the Plasma of Normal and Hypertensive Rabbits, J. Physiol. (Lond.), 170, 212.

Lever, A. F., Robertson, J. I. S. and Tree, M. (1963): The Assay of Renin in Rabbit Plasma. Mem. Soc. Endocrin. No. 13. "Hormones and the Kidney". Ed. P. C. Williams, pp. 285-291. London: Academic Press.

Lever, A. F., Robertson, J. I. S. and Tree, M. (1964): The Estimation of Renin in Plasma by an Enzyme Kinetic Technique, Biochem. J., 91, 346.
Lever, A. F. (1965): The Vasa Recta and Countercurrent Multiplication, Acta med. Scand., 178 , Suppl. 434, 1.

LeyssaC, P. P. (1964): The in vivo Effect of Angiotensin on the Proximal Tubular Reabsorption of Salt in Rat Kidneys, Acta physiol. Scand., 62, 449.

LEwIS, G. P. and Reit, E. (1965): The Action of Angiotensin and Bradykinin on the Superior Cervical Ganglion of the Cat, J. Physiol. (Lond.), 179, 538.

Low, J. A., Johnston, E. E. and McBride, R. L (1965): Blood Volume Adjustments in the Normal Obstetric Patient with Particular Reference to the Third Trimester of Pregnancy, Amer. J. Obstet. Gynec, 91, 356.

LCwE, R. D. (1964): Factors Controlling the Release of Renin from the Kidney, Lancet, ii, 183.

LUETSCHER, J. A., and AXELRAD, B. J. (1954): Increased Aldosterone Output during Sodium Deprivation in Normal Men, Proc. Soc. exp. Biol. (N.Y.), 87, 650.

Luetscher, J. A., and Curtis, R. H. (1955): Aldosterone: Observations on the Regulation of Sodium and Potassium Balance, Ann. intern. Med. 43, 658.

Luetscher, J. A., Camargo, C. A., Cohn, A. P., Dowdy, A. J. and Callaghan, A. M. (1963): Observations on the Metabolism of Aldosterone in Man, Ann. intern. Med., 59, 1.

Maebashi, M., Yoshinaga, K., Aida, M., OKuyama M. and Oikawa, A. (1965): Assay of Plasma Renin Substrate in Man, Tohoku J. exp. Med., 85 299.

MCCANCE, R. A. (1936): Experimental Sodium Chloride Deficiency in Man, Proc. roy. Soc. $B$, 119, 245.

MEYER, E. (1905): Uber Diabetes Insipidus und andere Polyurien, Dtsch. Arch. klin. Med., 83, 1.

Mills, J. N. (1962): Aldosterone Secretion in Man, Brit. med. Bull., 18, 170.

Moffat, D. B. and Fourman, J. (1963): The Vascular Pattern of the Rat Kidney, J. Anat. (Lond.), 97 543.

MorRis, R. E. and Robinson, P. R. (1964): A Method for Determination of Angiotensin II in Blood, Bull. Johns Hopk. Hosp., 114, 127.

Morris, R. E., Robinson, P. R. and SCHEEle, G. A. (1964): The Relationship of Angiotensin to Renal Hypertension, Canad. med. Ass. J., 90, 272.

Muller, A. F., Riondel, A. M., Manning, E. and MACH, R. S. (1956) (a): Etude de l'aldosteronurie chez le Sujet Normal et chez Cardiac oedemateaux, Schweiz. med. Wschr., 86, 1335.

Muller, A. F. (1958): In Aldosterone. Edited by A. F. Muller and C. M. O'Connor. pp. 211-212. London: J. and A. Churohill.

Muller, A. F., Manning, E. L. and Riondel, A. M (1958): Diurnal Variation of Aldosterone Related to Position and Activity in Normal Subjects and Patients with Pituitary Insufficiency. in Aldosterone. Edited by A. F. Muller and C. M. O'Connor pp. 111-127. London: J. and A. Churchill.

Muller, A. F., Riondel, A. M. and MACH, R. S (1956) (b): Control of Aldosterone Excretion by Changes in Body-fluid, Lancet i, 831.

Mulrow, P. J. and GANONG, W. F. (1961a): Stimulation of Aldosterone Secretion by Angiotensin II. Yale J. Biol. Med., 33, 386.

Mulrow, P. J. and Ganong, W. F. (1961b): Evidence 
of Secretion of an Aldosterone-stimulating Substance by the Kidney, Nature (Lond.), 190, 1115 .

Mulrow, P. J. (1964): The Role of the Reninangiotensin System in the Hypertension Associated with Renal Vascular Disease, Canad. med. Ass. J., $90,277$.

NIJENSOHN, C. M. (1957): Accion de la Hipertensina $O$ Angiotonina en la Hypertension Arterial Humana. Sem. méd., (B. Aires) 111, 205.

Nowaczynski, W., Kolw, E., Biron, P., Chretien, M. and GENEST, J. (1962): Effects of Angiotensin Infusions on Urinary Excretion of Compound III and Substances other than Aldosterone, Canad. J. Biochem., 40, 727.

Ontes, J. A., Melmon, K., Sjoerdsma, A., Gillespie, L. and MASON, D. T. (1964): Release of a Kinin Peptide in the Carcinoid Syndrome, Lancet, i, 514.

OGden, E. (1944): Physiological Significance of the Renal Pressor Mechanism, Tex. Rep. Biol. Med., 2. 345 .

Ostrovsky, D. and Gornall, A. G. (1964): Effects of Aldosterone and other Adrenal Hormones on the Blood Pressure Responses to Renin and Angiotensin, Canad. med. Ass. J., 90, 180.

PAGE, I. H. and BumpuS, F. M. (1961): Angiotensin, Physiol. Rev., 41, 331.

PARKer, R. A. (1964): The Microdissection and Staining of the Juxtaglomerular Apparatus in the Rabbit Kidney, J. Physiol. (Lond.), 171, 31P.

Peart, W. S. (1955): A New Method for the Largescale Preparation of Hypertensin, with a Note on its Assay, Biochem. J., 59, 300.

PEART, W. S. (1956): The Isolation of a Hypentensin, Biochem. J., $62,520$.

PearT, W. S. (1959): Hypertension and the Kidney, Brit. med. J., ii, 1353 and 1421.

PEART, W. S. and Brown, J. J. (1961): Effect of Angiotensin on Urine Flow and Eleotrolyte Excretion in Hypertensive Patients, Lancet, i, 28.

PearT, W. S. (1965): The Renin-angiotensin System, Pharmacol. Rev., 17, 143.

Peart, W. S., Lloyd, A. M., Payne, N. N., Stone, N. E., Thatcher, G. and LeVER, A. F. (1965): Purification of Pig Renin, Biochem. J., 96, 31C.

Peters, G. (1962): Angiotensin and Renal Function, Proc. Soc. exp. Biol. Med., 112, 771.

Pickens, P. T., Bumpus, F. M., Lloyd, A. M., SMEBY, R. R. and PAGE, I. H. i(1965): Measurement of Renin Activity in Human Plasma, Circulat. Res., 17, 438.

Pickering, G. W. and Prinzmetal, M. (1938): Some Observations on Renin a Pressor Substance Contained in the Normal Kidney, together with a Method for its Biological Assay, Clin. Sci., 3, 211.

Pickering, G. W. and Prinzmetal, M. (1940): The Effect of Renin on Urine Formation, J. Physiol. (Lond.), 98, 314.

Pickering, G. W., Prinzmetal, M. and Kelsall, A. R. (1942): The Assay of Renin in Rabbits with Experimental Renal Hypertension, Clin. Sci., 4, 401.

PiCKering, G. W. (1955): High Blood Pressure, London: J. and A. Churchill.

Pickering, G. W. (1965): Hyperpiesis, Brit. med. J. ii, 959 and 1021 .

REGOLI, D. and VANE, J. R. (1964): The Release and Detection of Angiotensin and of Catechol Amines in the Circulation of the Dog, J. Physiol. (Lond.), 172, 34P.

REICH, M. (1962): Variations in Urinary Aldosterone
Levels of Normal Females during their Menstrual Cycle, Aust. Ann. Med., 11, 41.

ReinerT, H., Davey, M. J., Brown, J. J., Davies, D. L., LEVER, A. F., and RoberTSON, J. I. S. (1966): In preparation.

Relman, A. S. (1963): The Diagnosis of Primary Aldosteronism. Boerhaave Symposium: Hypertension. Ed. J. de Graeff. pp. 248-256. Leyden University.

Robertson, J. I. S., Peart, W. S. and Andrews, T. M. (1962): Mechanism of Facial Flushes in the Carcinoid Syndrome, Quart. J. Med., 31, 103.

Rondell, P. A., McVaugh, R. B. and Bohr, D. F. (1958): Evidence for Humoral Factors in Renoprival Hypertension, Circulation, 17, 708.

SANDERS, L. L. and MelBY, J. C. (1964): Aldosterone and the Edema of Congestive Heart Failure, Arch. intern. Med., 113, 331.

Schlegel, J. U., SAVlov, E. D., and Gabor, F. (1959): Some Studies in Renal Hypertension, $J$. Urol. (Baltimore), 81, 581.

SCHMID, H. E. (1962): Renin, a Physiologic Regulator of Renal Hemodynamics, Circulat. Res., 11, 185.

SchwartZ, W. B., BenNetT, W., Curelop, S. and BARTTER, F. C. (1957): Syndrome of Renal Sodium Loss and Hyponatremia probably Resultirig from Inappropriate Secretion of Antidiuretic Hormone, Ann. intern. Med., 51, 1420.

SCornik, O. A. and Paladini, A. C. (1961): Angiotensin Blood Levels in Dogs with Experimental Renal Hypertension, Amer. J. Physiol., 201, 526.

SelKuRT, E. E. (1951): Effect of Pulse Pressure and Mean Arterial Pressure Modification on Renal Haemodynamics and Electrolyte and Water Excretion, Circulation, 4, 541.

SHARE, L. (1962): Vascular Volume and Blood Level of ADH, Amer. J. Physiol. 202, 791.

SHERLOCK, S. (1963): Diseases of the Liver and Biliary System. 3rd Edition. Oxford: Blackwell.

SkeGgS, L. T., MarSh, W. M., KAHN, J. R. and SHUMWAY, N. P. (1954): The Existence of two Forms of Hypertensin, J. exp. Med., 99, 275.

SkegGS, L. T., MARSH, W. M., KAHN, J. R. and Shumway, N. P. (1955): Amino-acid Composition and Electrophoretic Properties of Hypertensin I, J. exp. Med., 102, 435.

SKeGGS, L. T., KaHN, J. R. and ShumWaY, N. P. (1956): The Preparation and Function of the Hypertensin-converting Enzyme, J. exp. Med., $103,295$.

Skeggs, L. T., Lentz, K. E., Hochstrasser, H. and KAHN, J. R. (1963): The Purification and Partial Characterisation of Several Forms of Hog Renin Substrate, J. exp. Med., 118, 73.

Skinner., S. L., MoCubbin, J. W. and Page, I. H. (1964): Renal Baroreceptor Control of Acute Renin Release in Normotensive, Nephrogenic and Neurogenic Hypertensive Dogs, Circulat. Res., 15, 522.

Slater, J. D. H. (1963): In discussion: Mem. Soc. Endocrin. No. 13. "Hormones and the Kidney". Ed. P. C. Williams. pp. 377-378. London: Academic Press.

Slater, J. D. H., Barbour, B. H., Henderson, H. H., CASPER, A. G. T. and BARTTER, F. C. $(1965)$ : Physiological Influence of the Kidney on the Secretion of Aldosterone, Corticosterone and Cortisol by the Adrenal Cortex, Clin Sci., 28, 219.

Slaton, P. E. and Biglieri, E. G. (1965): Hypertension and Hyperaldosteronism of Renal and 
Adrenal Origin, Amer. J. Med., 38, 324.

Soghikian, K. and LAMeiJer, L. D. F. (1963): The Action of Angiotensin in Dogs. Boerhaave Symposium: Hypertension. Ed. J. de Graeff. pp. 180189. Leyden University.

Stakemann, G. (1960): A Renin-like Pressor Substance Found in the Placenta of the Cat, Acta path. microbiol. scand., 50, 350.

Stamey, T. A., Nudelman, I. J., Good, P. H., SCHWENTKER, F. N. and HENDRICKS, F. (1961) Functional Characteristics of Renovascular Hypertension, Medicine (Baltimore), 40, 347.

Strauss, M. B. (1957): Body Water in Man. London: J. and A. Churchill.

SwanN, H. G., Railey, M. J. and Carmignani, A. E. (1959): Functional Distension of the Kidney in Perinephritic Hypertension, Amer. Heart. J., 58, 608.

TAgGART, J. and DRURY, D. R. (1940): Action of Renin on Rabbits with Renal Hypertension, J. exp. Med., 71, 857.

TAIT, S. A. S. (1964): Aldosterone. Edited by E. E. Baulieu and P. Robel. p. 512. Oxford: Blackwell.

Tait, J. F., Bougas, J., LitTle, B., Tait, S. A. S. and FlOOD, C. (1965): Splanchnic Extraction and Clearance of Aldosterone in Subjects with Minimal and Marked Cardiac Dysfunction, J. clin. Endocrin., 25, 219.

ThURAU K. (1964): Renal Hemodynamics, Amer. J. Med., 36, 698.

Tigerstedt, R. and Bergman, P. G. (1898): Niere und Kreislauf, Skand. Arch. Physiol., 8, 223.

Tóbian, L. (1960a): Physiology of the Juxtaglomerular Cells. Ann. intern. Med., 52, 395.

ToBiaN, L. (1960b): Inter-relationship of Electrolytes, Juxtaglomerular Cells and Hypertension, Physiol. Rev., 40, 280.

Tobian, L. (1964): Sodium, Renal Artery Distension and the Juxtaglomerular Apparatus, Canad. med. Ass. J., 90, 160.

Trueta, J., Barclay, A. E., Daniel, P. M., Franklyn, K. J. and Prichard, M. M. L. (1947): Studies of the Renal Circulation. Oxford: Blackwell.

Ulick, S., LaRagh, J. H. and Lieberman, S. (1958): The Isolation of a Urinary Metabolite of Aldosterone and its use to Measure the Rate of Secretion of Aldosterone by the Adrenal Cortex of Man, Trans. Ass. Amer. Phycns., 71, 225.

URQuharT, J., Davis, J. $O$. and Higgins, J. T. (1963): Effects of Prolonged Infusion of Angiotensin II in Normal Dogs, Amer. J. Physiol., 205, 1241.

URQuharT, J. and Davis, J. O. (1963): Role of the Kidney and the Adrenal Cortex in Congestive Heart Failure, Mod. Conc. cardiov. Dis., 32, 781.

VANDER, A. J. and Miller, R. (1964): Control of Renin Secretion in the Anaesthetized Dog, Amer. J. Physiol., 207, 537.

Venning, E. H., Dyrenfurth, I., Giroud, C. J. P., and BECK, J. C. (1957): Factors Affecting Aldosterone Excretion, Canad. med. Ass. J., 77, 773.

Verniory, A., Enderle, J., Potvliege, R. Primo, G., Gregoire, F., Vereerstraeten, $P$. and StuCKENS, M. Diagnostic et Traitment de l' hypertension Rénovasculaire. (In discussion), Acta. clin. belg. (To be published).

Veyrat, R., DE Champlain, J., Boucher, R. and GENEST, J. (1964): Measurement of Human Arterial Renin Activity in Some Physiological and Pathological States, Canad. med. Ass J., 90, 215.

Vincent,, W. A., Kashemsant, U., Cuddy, R. P., Fried, A. H., SMulyan, H. and Eich, R. H. (1965): Vanillydmandelic Acid Excretion in Labile Hypertensive Subjects; Variation and Response to Norepinephrine and Angiotensin Infusion, Amer. J. med. Sci., 249, 79.

Watanabe, M., Meeker, C. I., Gray, M. J., Sims, E. A. M. and ScLomon, S. (1963): Secretion Rate of Aldosterone in Normal Pregnancy, J. Clin. Invest., 42, 1619.

Weinstein, H., Berne, R. M. and SACHS, H. (1960): Vasopressin in Blood: Effects of Haemorrhage, Endocrinology, 66, 712.

Werle, E., BAUMeister, K. and Schmal, A. (1962): Uber das Reninahnliche Enzym der Glandula Submaxillaris der Weissen Maus, Arch. exp. Path. Pharm., 244, 21.

Wilson, C. and Pickering, G. W. (1938): Acute Arterial Lesions in Rabbits with Experimental Renal Hypertension, Clin. Sci., 3, 343.

WILSON, C. and BYROM, F. B. (1939): Renal Changes in Malignant Hypertension; Experimental Evidences Lancet, i, 136.

WILSON, C. (1963): Experimental Renal Hypertens sion. Boerhaave Symposium: Hypertension. Eda J. de Graeff. pp. 74-82. Leyden University.

Wolf, A. V. (1958): Thirst; Physiology of the Urge to Drink and Problems of Water Lack, Springfield, Illinois: Charles C. Thomas.

WOLFF, H. P., KOCZOREK, K. R. and BuCHBORN, E. (1957): Hyperaldosteronism in Heart Disease, Lancet, ii, 63.

WolfF, H. P., KoczoreK, K. R. and Buchborn, E. (1958): Aldosteronuria in Oedema. Aldosterone. Edited by A. F. Muller and C. M. O'Connor. pp. 193-206. London: J. and A. Churchill.

WolfF, H. P. and ToRBICA, M. (1963): Determination of Plasma-aldosterone, Lancet, i, 1346.

WOODBURY, D. M. and KOCH, A. (1957): Effects of Aldosterone and Deoxycorticosterone on Tissue Electrolytes, Proc. Soc. exp. Biol. Med., 94, 720.

WrigHT, R. D. (1963a): Control of Aldosterone Secretion, Lancet, ii, 739.

WRIGHT, R. D. (1963b): Control of Aldosterone Secretion, Lancet, ii, 1168.

YAMAUCHI, H., BIGLIERI, E. G. and HoPPER, J. (1961): Blood Volume and Aldosterone Secretion in Hypertension and Primary Aldosteronism, Proc. Soc. exp. Biol. (N.Y.), 107, 728. 